\title{
A EFETIVIDADE DO DIREITO À LIBERDADE DE EXPRESSÃO PELO CONTROLE DE CONVENCIONALIDADE: A (DES)CRIMINALIZAÇÃO DO DESACATO NO BRASIL E OS IMPACTOS NO DIREITO DA PERSONALIDADE
}

\author{
THE EFFECTIVENESS OF THE RIGHT TO FREEDOM OF EXPRESSION FOR THE \\ CONVENTIONALITY CONTROL: THE (DE) CRIMINALIZATION OF THE CONTEMPT IN \\ BRAZIL AND THE IMPACTS IN THE LAW OF PERSONALITY
}

\section{Daniela Menengoti Ribeiro}

\begin{abstract}
Professora do Programa de Mestrado e Doutorado em Direito do Centro Universitário de Maringá Unicesumar. Pesquisadora do Instituto Cesumar de Ciência, Tecnologia e Inovação (ICETI). Doutora em Direito-Relações Econômicas Internacionais pela Pontifícia Universidade Católica de São Paulo - PUC/SP com período de pesquisa (doutorado sanduíche) na Université Paris 1 - Panthéon-Sorbonne, França. E-mail: daniela.menengoti@gmail.com
\end{abstract}

\section{Gabriel Antonio Roque}

Pós-graduando em Ciências Penais pela Universidade Estadual de Maringá (UEM). Bacharel em Direito pelo Centro Universitário de Maringá (UniCesumar), com período de mobilidade acadêmica (2017/2018) em Direito e Criminologia na Faculdade de Direito da Universidade do Porto (FDUP), Portugal. Membro de Grupos de Pesquisa (CNPQ). Bolsista PROBIC/UniCesumar de Iniciação Científica 2016-2017, bolsista da Fundação Nacional de Desenvolvimento do Ensino Superior Particular (Funadesp) 2017-2018 e bolsista PIBIC/UniCesumar de Iniciação Científica 2018-2019 e 2019-2020. Advogado (OAB/PR 102.815). E-mail: gabriel.antonioroque@outlook.com

Recebido em: 23/07/2019

Aprovado em: 10/06/2020

\begin{abstract}
RESUMO: O presente trabalho analisa o conflito do direito à liberdade de expressão garantido de forma ampla na Convenção Americana sobre Direitos Humanos (Pacto de San Jose da Costa Rica) e caracterizado como direito da personalidade que possibilita o pleno desenvolvimento da pessoa, frente à tipificação do crime de desacato previsto no Código Penal brasileiro. Objetiva, assim, refletir sobre a incompatibilidade dos delitos de desacato com o direito à liberdade de expressão e pensamento, analisando, para tanto, o posicionamento dos órgãos do Sistema Interamericano de Proteção dos Direitos Humanos sobre o tema. Como problema, questiona-se a efetivação do direito à liberdade de expressão no Brasil, por meio do exercício da jurisdição pelos órgãos estatais competentes, via controle de convencionalidade. Ao se valer de raciocínio hipotético-dedutivo, por meio de pesquisa documental, doutrinária e jurisprudencial, descritiva e exploratória, o artigo conclui que nas Cortes superiores brasileiras (Superior Tribunal de Justiça e Supremo Tribunal Federal), as recentes decisões tomadas via alegação de inconvencionalidade pelo controle difuso, desenham o cenário de manutenção do tipo penal do desacato, ensejando a possibilidade de futura condenação do Brasil pela Corte Interamericana de Direitos Humanos.
\end{abstract}


Palavras-chave: Liberdade de expressão; Desacato; Direitos da personalidade; controle de convencionalidade; efetividade.

\begin{abstract}
This work analyzes the conflict which the right to freedom of expression (guaranteed in a broad way in the American Convention on Human Rights Pact of San Jose, Costa Rica and characterized as a personality right which allows the person's full development) presents for the Brazilian Penal code as it relates to crimes of contempt. It reflects on the incompatibility of contempt crimes with the right to freedom of expression and thought, focusing for this purpose on the authorities of the Inter-American Court of Human Rights positions on the subject. It addresses the problem of the effectiveness of the right to freedom of expression in Brazil, through the exercise of jurisdiction by the legitimate state office through the conventionality control. By using hypothetical-deductive reasoning through documentary doctrinal and jurisprudential descriptive and exploratory research, the article concludes that the Brazilian (Superior Court Justice and Federal Supreme Court), the recent decisions taken on the grounds of unconventionality by the diffuse control, design the scenario maintaining the criminal type of contempt and allowing for the possibility of future condemnation of Brazil by the Inter-American Court of Human Rights.
\end{abstract}

Keywords: Freedom of expression; contempt; Personality rights; conventionality control; effectiveness.

SUMÁRIO: Introdução; 1 Reflexões sobre o crime de desacato e o direito à liberdade de expressão; 1.1 Ontologia da liberdade de expressão; $1.2 \mathrm{O}$ posicionamento da CIDH e da Corte IDH sobre a liberdade de expressão; 2 Controle de constitucionalidade e convencionalidade: instrumentos de efetivação de direitos; $2.1 \mathrm{O}$ controle de convencionalidade do crime de desacato na jurisprudência brasileira; Considerações finais; Referências.

\title{
INTRODUÇÃO
}

O atual Código Penal pátrio institui pena de detenção, de seis meses a dois anos, ou multa, a quem "[d] esacatar funcionário público no exercício da função ou em razão dela"1. Trata-se da figura típica denominada desacato, constituindo crime comum e de menor potencial ofensivo.

Presente nos diplomas penais brasileiros de 1830 e 1890, a figura típica enfrenta, ultimamente, variados questionamentos, em grande parte devido à emergência do Estado Constitucional e Democrático de Direito e sua consequente proteção à pessoa humana de forma extensa, tutelando a dignidade humana e os direitos da personalidade de forma abrangente. Isso aliado ao avanço da internacionalização da proteção aos direitos humanos, que no Brasil ocorre, dentre outras formas, através do Sistema Interamericano de proteção aos Direitos Humanos.

Neste sentido, tanto a Comissão quanto a Corte Interamericana de Direitos Humanos, tal figura penal, que visa à proteção da autoridade estatal, não subsistiria no atual ordenamento jurídico por violar o direito à liberdade de expressão e de pensamento garantido na Convenção Americana de Direitos Humanos.

Reconhecendo que o exercício da jurisdição estatal não se restringe em proteger direitos fundamentais, mas também em promover sua efetivação, busca-se analisar o controle de convencionalidade como meio de implementação de um sistema de garantias de direitos, que respeite a Constituição e os compromissos com tratados de direitos humanos.

Para tanto, far-se-á uma reflexão sobre o crime de desacato e o direito à liberdade de expressão, passando pela visão ontológica do instituto da liberdade de expressão, e pelo

\footnotetext{
${ }^{1}$ BRASIL. Decreto-lei no 2.848, de 7 de dezembro de 1940. Código Penal. Portal da Legislação, Brasília, DF, 31 dez. 1940. Disponível em: www.planalto.gov.br. Acesso em: 12 mai. 2019.
}

Revista de Direito Brasileira | Florianólopis, SC | v. 25 | n. 10 | p. 221-249 | Jan./Abr. 2020 
posicionamento dos órgãos do Sistema Interamericano de proteção dos Direitos Humanos sobre o tema. Posteriormente, passa-se pela análise do controle de constitucionalidade e convencionalidade, como instrumentos de para o exercício da função jurisdicional do Estado, prestada pelos órgãos competentes.

Ao se valer de raciocínio hipotético-dedutivo, analisa-se o problema da incompatibilidade dos delitos de desacato com a liberdade de expressão e pensamento, considerou-se o controle de convencionalidade para efetivação do direito contemplado na Convenção Americana de Direitos Humanos. A pesquisa é realizada pelo meio documental, doutrinária e jurisprudencial, descritiva e exploratória, e conclui que as recentes decisões tomadas via alegação de inconvencionalidade pelo controle difuso, desenham o cenário de manutenção do tipo penal do desacato no Brasil.

Ao se flagelar a liberdade de expressão, viola-se também outros preceitos fundamentais, dentre os quais destaca-se a dignidade humana, fundamento da República Federativa do Brasil e o direito da personalidade, que, por sua vez, se concretiza com o pleno desenvolvimento da pessoa a partir do acesso à informação como meio de conhecer a realidade e interpretá-la, da possibilidade de participar de um debate livre e desinibido, e da liberdade de crítica ao governo como meio indispensável para seu controle. Tais violações, ensejando a possibilidade de futura condenação do Brasil pela Corte Interamericana de Direitos Humanos.

\section{REFLEXÕES SOBRE O CRIME DE DESACATO E O DIREITO À LIBERDADE DE EXPRESSÃO}

O "desacato" tem origem no Direito Antigo e no Direito Romano, quando as injúrias cometidas contra magistrados no exercício de suas funções eram denominadas iniuria atrox e a sanção pecuniária era estabelecida contra a classe dos humiliores $^{2}$. Atualmente, consiste no tipo penal que criminalizam a expressão que ofende, insulta ou ameaça o funcionário público no desempenho de suas funções.

O Código Penal pátrio vigente, de 1940, institui em seu art. 331, a pena de detenção, de seis meses a dois anos, ou multa, a quem "[d]esacatar funcionário público no exercício da função ou em razão dela"3. A figura tipificada por "desacato", inserta no capítulo que trata dos crimes praticados por particulares contra a administração em geral, é classificado de crime comum e de menor potencial ofensivo, de competência do Juizado Especial Criminal ${ }^{4}$.

O desacato, no entanto, não se trata de figura nova no ordenamento jurídico pátrio, e isso não se deve somente ao fato do atual Código datar da Era Vargas. ${ }^{5} \mathrm{O}$ primeiro Código Penal brasileiro, de 1830, já trazia os denominados "crimes contra o livre exercicio dos Poderes Politicos" $"$, que, apesar de receberem outros nomen juris, remetem à figura típica do desacato. Já o Código Penal de 1890, do início da República, trazia o capítulo "Desacato e desobediencia ás

\footnotetext{
${ }^{2}$ PRADO, Luiz Régis. Curso de direito penal brasileiro. Vol. 4. São Paulo: Revista dos Tribunais, 2002 , p. $506-507$. ${ }^{3}$ BRASIL. Decreto-lei no 2.848, de 7 de dezembro de 1940. Código Penal. Portal da Legislação, Brasília, DF, 31 dez. 1940. Disponível em: www.planalto.gov.br. Acesso em: 12 mai. 2019.

${ }^{4}$ BRASIL. Lei no 9.099, de 26 de setembro de 1995. Dispõe sobre os Juizados Especiais Cíveis e Criminais e dá outras providências. Portal da Legislação, Brasília, DF, 26 de setembro de 1995. Disponível em: www.planalto.gov.br. Acesso em: 12 mai. 2019.

${ }^{5} \mathrm{Na}$ legislação nacional, o Código Penal Militar de 1969, prevê, ainda, as figuras de desacatos no art. 299 (desacato a militar), art. 300 (desacato a assemelhado ou funcionário) e 341 (desacato à autoridade judiciária militar). In: BRASIL. Decreto-lei $n^{\circ}$ 1.001, de 21 de outubro de 1969. Código Penal Militar. Portal da Legislação, Brasília, DF, 21 out. 1969. Disponível em: www.planalto.gov.br. Acesso em: 12 mai. 2019.

6 “art. 93. Usar de violencia, ou de ameaças contra qualquer membro das Camaras Legislativas, ou para melhor influir na maneira de se portar no exercicio de seu emprego, ou pelo que tiver dito, ou praticado no mesmo exercicio. Penas - de prisão com trabalho por seis mezes a quatro annos, além das mais, em que incorrer pela violencia, ou ameaças". In: BRASIL. Lei de 16 de dezembro de 1830. Manda executar o Codigo Criminal. Portal da Legislação, Brasília, DF, 16 dez. 1830. Disponível em: www.planalto.gov.br. Acesso em: 13 mai. 2019.
}

Revista de Direito Brasileira | Florianólopis, SC | v. 25 | n. 10 | p. 221-249 | Jan./Abr. 2020 
autoridades", e definia como crime (art. 134) "[d]esacatar qualquer autoridade, ou funccionario publico, em exercicio de suas funcções, offendendo-o directamente por palavras ou actos, ou faltando á consideração devida e á obediencia hierarchica", com pena de "prisão cellular por dous a quatro mezes, além das mais em que incorrer", e dispunha ainda que "[s]i o desacato for praticado em sessão pública de camaras legislativas ou administrativas, de juizes ou tribunaes, de qualquer corporação docente ou dentro de alguma repartição publica" teria um aumento de pena de $1 / 3$. $^{7}$

Nota-se que qualquer ultraje às pessoas que exercem funções públicas seria caracterizado como uma ofensa ao próprio estado. Em uma análise topográfica, ter-se-ia como bem jurídicopenal tutelado, a dignidade ou a respeitabilidade da administração pública. Assim, a pessoa do funcionário público estaria relegada a um segundo plano, buscando-se proteger, efetivamente, o funcionário público em razão da função pública exercida ${ }^{8}$.

Sobre essa análise, pode-se afirmar que o próprio conceito de Estado, firmado na história, traz a ideia de superioridade face o cidadão. Desde o modelo proposto por Hobbes, que fomentou o absolutismo monárquico, o Estado já era identificado como um "deus mortal, ao qual devemos, abaixo do Deus Imortal, nossa paz e defesa"9.

Verifica-se, no entanto, uma tendência de ideias mais recente que busca amenizar as assimetrias entre o Estado e o indivíduo, e que passa olhar os Estados nacionais como uma estrutura da sociedade mundial que opera em favor das expectativas dos indivíduos ${ }^{10}$, e a discussão acerca do direito à liberdade de expressão está envolvida nesta reflexão.

\subsection{Ontologia da liberdade de expressão}

Torna-se oportuno, neste ponto, realizar apontamentos acerca do direito à liberdade de expressão, sem a pretensão de esgotar a matéria. A discussão acerca da matéria é rica, repleta de complexidades e questionamentos, e envolve elementos interdisciplinares, o que não possibilita uma avaliação limitada.

No âmbito jurídico, a liberdade de expressão é reconhecida pela Constituição da República Federativa do Brasil como um direito fundamental, assegurando-se no art. $5^{\circ}$ : a livre manifestação do pensamento, sendo vedado o anonimato (inc. IV); a livre expressão da atividade intelectual, artística, científica e de comunicação, independentemente de censura ou licença (inc. IX); e o acesso, à todos, à informação, resguardado o sigilo de fonte quando necessário ao exercício profissional (no inc. XIV). ${ }^{11}$

Para a Convenção Americana de Direitos Humanos (Pacto de São José da Costa Rica), a liberdade de expressão está prevista em seu art. 13 (Liberdade de pensamento e de expressão) nos seguintes termos:

1. Toda pessoa tem direito à liberdade de pensamento e de expressão. Esse direito compreende a liberdade de buscar, receber e difundir informações e idéias de toda natureza, sem consideração de fronteiras, verbalmente ou por escrito, ou em forma impressa ou artística, ou por qualquer outro processo de sua escolha.

\footnotetext{
${ }^{7}$ BRASIL. Decreto no 847, de 11 de outubro de 1890. Promulga o Codigo Penal. Portal da Legislação, Brasília, DF, 11 out. 1890. Disponível em: www.planalto.gov.br. Acesso em: 13 mai. 2019.

${ }^{8}$ MONTEIRO, Washington de Barros. O crime de desacato. Doutrinas Essenciais de Direito Penal, vol. 6, p. 443 450, DTR\2012\1581. São Paulo: Revista dos Tribunais, 2010, p. 443.

${ }^{9}$ HOBBES, Thomas. Leviatã ou matéria, forma e poder de um Estado eclesiástico ou civil. Tradução: Alex Marins. São Paulo. Ed. Martin Claret, 2002, p. 131.

${ }^{10}$ Conforme: DELMAS-MARTY, Mireille. Résister, responsabiliser, anticiper. Seuil: Paris, France, 2013; SALDANHA, Jania Maria Lopes. Cosmopolitismo jurídico: teorias e práticas de um direito emergente entre a globalização e a mundialização. Porto Alegre: Livraria do Advogado, 2018.

${ }^{11}$ BRASIL. Constituição da República Federativa do Brasil de 1988. Portal da Legislação, Brasília, DF, 5 de outubro de 1988. Disponível em: www.planalto.gov.br. Acesso em: 12 mai. 2019.
}

Revista de Direito Brasileira | Florianólopis, SC | v. 25 | n. 10 | p. 221-249 | Jan./Abr. 2020 
2. O exercício do direito previsto no inciso precedente não pode estar sujeito a censura prévia, mas a responsabilidades ulteriores, que devem ser expressamente fixadas pela lei e ser necessárias para assegurar:

a. o respeito aos direitos ou à reputação das demais pessoas; ou

b. a proteção da segurança nacional, da ordem pública, ou da saúde ou da moral públicas.

3. Não se pode restringir o direito de expressão por vias ou meios indiretos, tais como o abuso de controles oficiais ou particulares de papel de imprensa, de frequiências radioelétricas ou de equipamentos e aparelhos usados na difusão de informação, nem por quaisquer outros meios destinados a obstar a comunicação e a circulação de idéias e opiniões.

4. A lei pode submeter os espetáculos públicos a censura prévia, com o objetivo exclusivo de regular o acesso a eles, para proteção moral da infância e da adolescência, sem prejuízo do disposto no inciso 2.

5. A lei deve proibir toda propaganda a favor da guerra, bem como toda apologia ao ódio nacional, racial ou religioso que constitua incitação à discriminação, à hostilidade, ao crime ou à violência. ${ }^{12}$

Segundo a Corte Interamericana, o direito à liberdade de pensamento e expressão contam com uma "dimensão individual" (art. 13.1, primeira parte), que não se esgota no reconhecimento teórico do direito de falar ou escrever, mas que compreende o direito de utilizar qualquer meio apropriado para difundir o pensamento e fazê-lo chegar ao maior número possível de destinatários; e uma "dimensão social" (art. 13.1, in fine), constituindo um meio para o intercâmbio de ideias e informações entre as pessoas, compreendendo o direito das pessoas comunicarem às outras seus pontos de vista, implicando ainda no direito de todas as pessoas de conhecer opiniões, relatos e notícias. ${ }^{13}$

Segundo Valerio de Oliveira Mazzuoli, a disposição convencional em comento está voltada para o Estado, que por vezes, restringe esse direito do cidadão, censurando-o ou privandoo de externar seu pensamento ou de expressar sua opinião. "Trata-se, pois, de direito que constitui um dos pilares da sociedade democrática e uma das principais condições para que os integrantes de um Estado possam desenvolver-se plenamente, sem temor da censura e da opressão." ${ }^{14}$ Neste sentido, registra-se, que o exercício do direito à liberdade de pensamento e de expressão, ainda que não esteja sujeito à censura prévia, está condicionada a responsabilidades ulteriores, conforme estabelecido na Convenção (art. 13.2).

Oportuno resgatar, neste ponto, os princípios fundamentais do modelo político de democracia ateniense para pertencer ao espaço da polis, quais sejam: a liberdade de expressão, conquistada com o direito de discordar do Poder, e a igualdade de direitos, possibilitando o acesso do cidadão a esse Poder. $\mathrm{O}$ homem somente poderia exercer sua função política em liberdade, e só podia ser livre entre seus pares.

A forma de governo ateniense influenciou as sociedades que a sucederam, e refletiu nas cartas de direitos constitucionais os mais básicos compromissos da democracia: a liberdade e a

\footnotetext{
${ }^{12}$ BRASIL. Decreto no 678, de 6 de novembro de 1992. Promulga a Convenção Americana sobre Direitos Humanos (Pacto de São José da Costa Rica), de 22 de novembro de 1969. Portal da Legislação, Brasília, DF, 21 out. 1969. Disponível em: www.planalto.gov.br. Acesso em: 15 mai. 2019.

${ }^{13}$ COSTA RICA, Corte Interamericana de Derechos Humanos. Caso "La Última Tentación de Cristo" (Olmedo Bustos y otros) vs. Chile. Fondo, Reparaciones y Costas (Serie C No. 73, 2001), 05 de fevereiro de 2001, p. 27-28, §§ 64-66. Jurisprudencia, San José, Costa Rica, 22 de novembro de 2005. Disponível em: www.corteidh.or.cr. Acesso em 18 mai. 2019.

${ }^{14}$ MAZZUOLI, Valerio de Oliveira; GOMES, Luiz Flávio Gomes. Comentários à Convenção Americana sobre Direitos Humanos: Pacto de San José da Costa Rica. 4. ed. ver., atual. e ampl. São Paulo: Revista dos Tribunais, 2013, p. 176-177.
} 
igualdade dos seus cidadãos. ${ }^{15}$ Concebidos na antiguidade, esses ideais resistiram à evolução da sociedade, e ainda hoje são considerados os princípios cardeais da democracia moderna. A esses valores acrescentou-se outros - como o respeito aos direitos fundamentais e o cuidado ao princípio democrático - que completam o aspecto moderno do sistema político democrático.

A liberdade de pensamento e expressão, compõem, assim, o chamado "standard democrático, sem o qual o pleno desenvolvimento dos direitos humanos não se realiza. Por essa razão, são constantes da maioria dos ordenamentos constitucionais democráticos, e encontram eco na normativa internacional, sendo conditio sine qua non do Estado Constitucional e Humanista de Direito. $^{16}$

Corroborando para a "dimensão social” da liberdade de expressão destacada pela Corte IDH, Pablo Salvador Coderch aborda uma variedade de fundamentos deste direito, quais sejam: a busca da verdade; a possibilidade de um debate livre e desinibido; o entendimento da liberdade de expressão como derivada da dignidade humana, fundamento da República Federativa do Brasil (art. $1^{\circ}$, inc. III, CF/88); a liberdade de expressão como direito da personalidade que possibilita o pleno desenvolvimento da pessoa a partir do acesso à informação como meio de conhecer a realidade e interpretá-la; a proteção frente às interferências do poder estatal; a liberdade de expressão como instrumento para a manutenção da democracia; a liberdade de crítica ao governo como meio indispensável para seu controle ${ }^{17}$; entre outros pontos.

O filósofo britânico John Stuart Mill realiza em sua obra "Sobre a Liberdade" (On Liberty) de 1859, uma das mais influentes defesas da liberdade no pensamento moderno. ${ }^{18} \mathrm{O}$ autor defende uma liberdade de expressão profunda e radical, asseverando que a livre discussão deve ser levada ao extremo. Para Mill, a própria liberdade de pensamento é indissociável da liberdade de expressão ${ }^{19}$, que consiste, justamente, na faculdade de externar através de gestos, falas, escritos etc., as próprias ideias do ser racional. A liberdade de expressão consiste, então, na exteriorização de opiniões, juízos de valor, críticas e ideias para manifestação do próprio pensamento humano.

Segundo John Stuart Mill, qualquer restrição à livre expressão e discussão seria um obstáculo ao desenvolvimento da humanidade, sendo que toda e qualquer ideia, opinião, teoria etc., deveria ser expressa praticamente sem qualquer limitação ou censura. ${ }^{20}$

Observa-se que a liberdade de expressão a ser garantida pelo Estado pressupõe uma atuação "negativa" por parte deste, classificando-se então como uma garantia fundamental de primeira geração, impedindo a censura e a interferência em um direito essencial à pessoa. Assim, constata-se que a doutrina da liberdade de expressão tem como consequência a imunização de certos atos frente a eventuais restrições que possam a vir sofrer ${ }^{21}$, sejam estas provenientes do particular ou do próprio Estado.

${ }^{15}$ BOBBIO, Norberto. Igualdade e liberdade. 3. ed. Tradução de Nelson Coutinho. Rio de Janeiro: Ediouro, 1997, p.
8.
${ }^{16}$ MAZZUOLI, Valerio de Oliveira; GOMES, Luiz Flávio Gomes. Comentários à Convenção Americana sobre Direitos Humanos: Pacto de San José da Costa Rica. 4. ed. ver., atual. e ampl. São Paulo: Revista dos Tribunais, 2013, p. 176.

${ }^{17}$ CODERCH, Pablo Salvador. El derecho de la libertad. Colección: Estudios Constitucionales. Madri, Espanha: Centro de Estudios Políticos y Constitucionales, 1993, p. 40.

${ }^{18}$ MACLEOD, Christopher. John Stuart Mill. The Stanford Encyclopedia of Philosophy. Spring 2017 Edition. Disponível em: https://plato.stanford.edu/archives/spr2017/entries/mill/. Acesso em: 16 jan. 2018.

${ }^{19}$ MILL, John Stuart. On Liberty. Kitchener: Batoche Books, 2001, p. 15-16.

20 "[...] the peculiar evil of silencing the expression of an opinion is, that it is robbing the human race; posterity as well as the existing generation; those who dissent from the opinion, still more than those who hold it. If the opinion is right, they are deprived of the opportunity of exchanging error for truth: if wrong, they lose, what is almost as great a benefit, the clearer perception and livelier impression of truth, produced by its collision with error." In: MILL, John Stuart. On Liberty. Kitchener: Batoche Books, 2001, p. 19.

${ }^{21}$ SCANLON, Thomas. A theory of freedom of expression. Philosophy \& Public Affairs, p. 204-226, vol. 1, no 2, 1972, p. 204. 
Contudo, o direito à liberdade de expressão, tão ou mais do que qualquer outra garantia do Estado Democrático, demanda desafios diários ao convício social, reclamando dificuldades e um preço que vale a pena ser pago para a sobrevivência do regime democrático. Nesse sentido, Daniel Sarmento assevera com precisão que:

O exercício da liberdade de expressão não é inofensivo. Muitas vezes as palavras e as idéias ferem e isto faz parte do jogo. Quando, por exemplo, a imprensa publica uma crítica totalmente desfavorável a uma obra literária, é muito provável que este ato cause grande tristeza ao seu autor - há casos até de suicídio -, e lhe traga também prejuízos materiais, pela diminuição das vendas do livro. Quando ela condena como antiéticos os atos de algum político, ela certamente abala a sua reputação e pode definir o seu fracasso numa eleição. Isto, porém, não justifica a proibição destes atos expressivos nem a penalização de quem os escreveu ou veiculou. Na verdade, a formação de um debate livre, robusto e aberto de idéias na sociedade é um dos objetivos fundamentais da liberdade de expressão, e neste debate alguns fatalmente saem arranhados. Este é um preço que vale a pena pagar para viver-se numa democracia. ${ }^{22}$

Tem-se claro que a liberdade de expressão não é um direito absoluto, encontrando limitações em outros direitos fundamentais também reconhecidos pela ordem jurídica brasileira e internacional, como o direito à honra, à intimidade e à vida privada, também consectários da dignidade da pessoa humana, devendo haver a ponderação entre os direitos quando porventura encontrem-se em confronto, buscando-se sua compatibilização ${ }^{23}$.

Não obstante, o aplicador do direito deve sempre ter em mente o peso conferido à liberdade de expressão enquanto direito fundamental, tendo em conta os fundamentos dessa garantia e seu intrínseco caráter instrumental em relação ao regime democrático e à soberania popular $^{24}$. Nesse sentido:

[...] tanto em sua manifestação individual, como especialmente na coletiva, entende-se que as liberdades de informação e de expressão servem de fundamento para o exercício de outras liberdades, o que justifica uma posição de preferência preferred position - em relação aos direitos fundamentais individualmente considerados. Tal posição, consagrada originariamente pela Suprema Corte americana, tem sido reconhecida pela jurisprudência do Tribunal Constitucional Espanhol e pela do Tribunal Constitucional Federal alemão. ${ }^{25}$

Defende-se, assim, o direito à liberdade de expressão e discussão enquanto meio de realização do próprio Estado Democrático de Direito, garantindo que o poder efetivamente emane do povo, diretamente ou através de seus representantes legais, conforme art. $1^{\circ}$, parágrafo único, da Constituição Federal de 1988. Assim, assumindo a liberdade de expressão como princípio fundamental e adotando a terminologia de Robert Alexy, tem-se que a norma mandamental de otimização "liberdade de expressão" deve receber um peso mais elevado quando ponderada com

\footnotetext{
22 SARMENTO, Daniel. A liberdade de expressão e o problema do 'Hate-Speech'. In: Cristiano Chaves de Farias. (Org.). Leituras Complementares de Direito Civil: O direito civil-constitucional em concreto. Salvador: Jus Podium, 2007, p. 37-95, p. 78-79.

${ }^{23}$ ALEXY, Robert. A Theory of Constitutional Rights. Trad. Julian Rivers. Oxford: Oxford University Press, 2002, p. 287.

${ }^{24}$ MACHADO, Jónatas Eduardo Mendes. Liberdade de expressão: Dimensões Constitucionais da Esfera Pública no Sistema Social. Boletim da Faculdade de Direito da Universidade de Coimbra. Coimbra: Coimbra Editora, 2002, p. 255-256.

${ }^{25}$ BARROSO, Luis Roberto. Colisão entre liberdade de expressão e direitos da personalidade. Critérios de ponderação. Interpretação constitucionalmente adequada do Código Civil e da Lei de Imprensa. Revista de direito administrativo, v. 235, p. 1-36, Rio de Janeiro, jan./mar. 2004, p. 20.
}

Revista de Direito Brasileira | Florianólopis, SC | v. 25 | n. 10 | p. 221-249 | Jan./Abr. 2020 
os demais princípios de um regime democrático, para a garantia, em última análise, do próprio regime. $^{26}$

Vale lembrar, que o bem jurídico-penal protegido de forma imediata pela figura do desacato não é a honra ou a intimidade da pessoa do servidor público, que, poderiam ser protegidas suficientemente pelos crimes contra a honra em geral (arts. 138 e seguintes do Código Penal), além da possibilidade das reparações cíveis cabíveis. O sujeito passivo imediato do crime de desacato é o próprio Estado, ou, dito de outro modo, a Administração Pública, restando em segundo plano a figura do funcionário público ${ }^{27}$. Assim, as situações em que seria possível afastar a liberdade de expressão em nome de princípios como a dignidade humana e a intimidade, ficam ainda mais restrito nesses casos.

Retomando a discussão, observa-se que tanto a Constituição de 1988 quanto a Convenção Americana de Direitos Humanos conferem proteção ampla à livre manifestação de pensamentos e opiniões. No ponto aqui abordado, referidos pensamentos e opiniões podem ser dirigidos aos funcionários estatais: não diretamente para a pessoa, mas para a própria Administração Pública e para o funcionário enquanto prestador de um serviço público, sujeito, portanto, ao escrutínio social em razão de suas funções. Assim, cumpre refletir até que ponto a criminalização do desacato tolhe ou impõe limites desarrazoados à liberdade de expressão enquanto direito fundamental, tendo em vista especialmente que, muitas vezes, a insatisfação com o serviço público prestado pode suscitar fortes críticas e até mesmo ofensas à Administração Pública.

Existindo a liberdade de expressão para "garantir o direito de se dizer o que as autoridades nem sempre querem ouvir" 28 , observa-se que este direito fundamental pode estar sendo ilegitimamente limitado pela criminalização do desacato, pois se está diante de inibições às críticas e de obstáculos às confrontações frente ao Estado (nas pessoas de seus funcionários).

\subsection{O posicionamento da CIDH e da corte IDH sobre a liberdade de expressão}

A Comissão Interamericana de Direitos Humanos (CIDH), órgão autônomo da Organização dos Estados Americanos (OEA) e que integra o Sistema Interamericano de Proteção dos Direitos Humanos (SIDH), vem, desde 1994, no Caso Horacio Verbitsky vs. Argentina, asseverando reiteradamente a incompatibilidade das chamadas "leis de desacato" com o direito à liberdade de expressão.

Nesse episódio, o jornalista Horacio Verbitsky foi condenado por desacato por ter chamado um ministro da Corte Suprema de Justiça da Argentina, Augusto Belluscio, de "asqueroso" em um artigo publicado no diário "Página 12". O caso foi solucionado de forma amistosa no âmbito da $\mathrm{CIDH}^{29}$, tendo a Argentina, como parte do acordo e atendendo o dever de adotar disposições de direito interno previsto no art. $2^{\circ}$ da Convenção ${ }^{30}$, derrogado o art. 244 de seu Código Penal que previa a figura do desacato.

\footnotetext{
26 "[...] principles are norms which require that something be realized to the greatest extent possible given the legal and factual possibilities". In: ALEXY, Robert. A Theory of Constitutional Rights. Trad. Julian Rivers. Oxford: Oxford University Press, 2002, p. 47.

${ }^{27}$ NUCCI, Guilherme de Souza. Código Penal Comentado. 15. ed. Rio de Janeiro: Forense, 2015, p. 1380.

${ }^{28}$ GUERRA, Gustavo Rabay; MARCOS, Henrique Jerônimo Bezerra. O drible continental: a margem de apreciação nacional na decisão de convencionalidade do crime de desacato pelo Superior Tribunal de Justiça. Revista da Faculdade de Direito UFPR, Curitiba, PR, Brasil, v. 63, n. 2, p. 173, ago. 2018. Disponível em: https://revistas.ufpr.br/direito/article/view/59194. Acesso em 17 jan. 2019.

${ }^{29}$ ORGANIZACIÓN DE LOS ESTADOS AMERICANOS. Comisión Interamericana de Derechos Humanos (CIDH), Decisiones, Solución Amistosa, Informe No 22/94, Caso 11012, Horacio Verbitsky, 20 de septiembre de 1994. Washington DC: OEA, 1994. Disponível em: www.cidh.oas.org. Acesso em: 10 mai. 2019.

30 “Artigo 2. Dever de adotar disposições de direito interno - Se o exercício dos direitos e liberdades mencionados no artigo 1 ainda não estiver garantido por disposições legislativas ou de outra natureza, os Estados Partes comprometemse a adotar, de acordo com as suas normas constitucionais e com as disposições desta Convenção, as medidas legislativas ou de outra natureza que forem necessárias para tornar efetivos tais direitos e liberdades." In: BRASIL. Revista de Direito Brasileira | Florianólopis, SC | v. 25 | n. 10 | p. 221-249 | Jan./Abr. 2020
} 
Valem, neste sentido, ser destacados, dentre tantos outros expedientes ${ }^{31}$, o Informe Anual da CIDH de $1994^{32}$ que destina um capítulo para a análise da compatibilidade entre as leis de desacato e a Convenção Americana, bem como a Declaração de Princípios Sobre a Liberdade de Expressão de $2000^{33}$ e o Informe Anual da Relatoria Para a Liberdade de Expressão de 2002.

No Informe de 1994, a CIDH conclui que as leis de desacato, além de desnecessárias para proteger a ordem pública, são incompatíveis com a Convenção Americana de Direitos Humanos por reprimirem a liberdade de expressão imprescindível ao funcionamento de um regime democrático ${ }^{34}$, além de conferirem aos funcionários públicos, de forma injustificada, uma proteção da qual não gozam os demais cidadãos. Apoiada nas lições de John Stuart Mill, afirma que as limitações à liberdade de expressão advindas da criminalização do desacato atingem de forma prejudicial não apenas quem critica, mas também toda a sociedade.

Para a CIDH, nos casos de ataques injustificados a resposta poderia vir, suficientemente, através dos meios de informação do governo ou através das ações cíveis individuais cabíveis por difamação ou calúnia, sendo que a penalização de qualquer manifestação de opiniões nesses casos, só deve ser admitida em situações muito excepcionais, quando houver risco direto e iminente de violências anárquicas. ${ }^{35}$

A Declaração de Princípios sobre a Liberdade de Expressão de 2000, por sua vez, reconhece que a liberdade de expressão, em todas as suas formas e manifestações, não é uma concessão dos Estados, mas sim um direito fundamental, inalienável e inerente à todas as pessoas, e um requisito indispensável a existência de uma sociedade democrática. Para a Declaração, as leis que penalizam a expressão ofensiva dirigida à funcionários públicos, atentam contra a liberdade de expressão e o direito à informação. ${ }^{36}$

Cabe destacar, ainda, a emblemática decisão da Corte IDH, instituição judicial autônoma no Sistema Interamericano, no Caso Palamara Iribarne vs. Chile. A despeito de não reconhecer, de forma geral, a inconvencionalidade do crime de desacato, a Corte realizou, no caso em comento, uma análise da proporcionalidade da tipificação do crime no Chile.

Decreto no 678, de 6 de novembro de 1992. Promulga a Convenção Americana sobre Direitos Humanos (Pacto de São José da Costa Rica), de 22 de novembro de 1969. Portal da Legislação, Brasília, DF, 21 out. 1969. Disponível em: www.planalto.gov.br. Acesso em: 15 mai. 2019.

${ }^{31}$ A CIDH disponibiliza informes anuais sobre o tema da liberdade de expressão nos países da Améroca. Ver a respeito em: ORGANIZACIÓN DE LOS ESTADOS AMERICANOS. Comisión Interamericana de Derechos Humanos (CIDH), Relatoría Especial para la Libertad de Expresión, Informes Anuales. Washington DC: OEA. Disponível em: www.oas.org. Acesso em: 10 mai. 2019.

${ }^{32}$ ORGANIZACIÓN DE LOS ESTADOS AMERICANOS. Comisión Interamericana de Derechos Humanos (CIDH), Informe anual de la Comisión Interamericana de Derechos Humanos 1994, OEA/Ser.L/V/II.88, Doc. 9 rev., 17 febrero 1995. Washington DC: OEA, 1995. Disponível em: www.cidh.oas.org. Acesso em: 10 fev. 2019.

${ }^{33}$ ORGANIZACIÓN DE LOS ESTADOS AMERICANOS. Comisión Interamericana de Derechos Humanos (CIDH), Declaración de Principios sobre Liberdad de Expresión 2000. Washington DC: OEA, 2000. Disponível em: https://www.cidh.oas.org/basicos/declaracion.htm. Acesso em: 16 fev. 2019.

34 "El término "necesario", en el contexto del artículo 13(2) debe considerarse como algo más que "útil”, "razonable”, o "conveniente". Para que una limitación sea "necesaria”, debe demostrarse que el fin legitimo que se persigue no puede alcanzarse razonablemente por un medio menos restrictivo de la libertad de expresión”. In: ORGANIZACIÓN DE LOS ESTADOS AMERICANOS. Comisión Interamericana de Derechos Humanos (CIDH), Informe anual de la Comisión Interamericana de Derechos Humanos 1994, OEA/Ser.L/V/II.88, Doc. 9 rev., 17 febrero 1995, Capitulo V, IV, “c”. Washington DC: OEA, 1995. Disponível em: www.cidh.oas.org. Acesso em: 10 fev. 2019.

${ }^{35}$ ORGANIZACIÓN DE LOS ESTADOS AMERICANOS. Comisión Interamericana de Derechos Humanos (CIDH), Informe anual de la Comisión Interamericana de Derechos Humanos 1994, OEA/Ser.L/V/II.88, Doc. 9 rev., 17 febrero 1995, Capitulo V, IV, “b”, “Conclusion”. Washington DC: OEA, 1995. Disponível em: www.cidh.oas.org. Acesso em: 10 fev. 2019.

${ }^{36}$ ORGANIZACIÓN DE LOS ESTADOS AMERICANOS. Comisión Interamericana de Derechos Humanos (CIDH), Declaración de Principios sobre Liberdad de Expresión 2000. Washington DC: OEA, 2000. Disponível em: www.cidh.oas.org. Acesso em: 16 fev. 2019.

Revista de Direito Brasileira | Florianólopis, SC | v. 25 | n. 10 | p. 221-249 | Jan./Abr. 2020 
Palamara Iribarne havia sido condenado, dentre outros crimes, por desacato (art. 264.3 do Código Penal chileno), com sentença confirmada pela Corte Suprema do Chile, em razão de declarações em uma conferência de imprensa, na qual criticou a procuradoria por sua atuação em um processo movido contra si, que envolvia a proibição, em 1993, da publicação do livro "Ética y Servicios de Inteligencia" de sua autoria. A obra tratava de assuntos relacionados à inteligência militar e a necessidade de sua adequação a padrões éticos, e, que segundo autoridades chilenas, atentava contra a segurança nacional.

A Corte IDH entendeu que o livro e as declarações publicadas na mídia, versavam sobre o conceito da dupla dimensão (individual e social) da liberdade de pensamento e expressão, bem como sua interdependência, uma vez que consagram o exercício do direito à liberdade de pensamento e expressão do Sr. Palamara Iribarne, como também promovem a dimensão social deste direito, através do acesso aos leitores às informações e opiniões expressadas. ${ }^{37}$

Sobre o fato de a vítima ter sido condenada internamente pelo crime de desacato, a Corte se posicionou no sentido de que tal condenação utilizou a persecução penal de uma forma desproporcional e desnecessária, suprimindo o debate essencial para o funcionamento de um sistema verdadeiramente democrático e restringindo sem qualquer necessidade o direito à liberdade de expressão e pensamento. ${ }^{38}$

Neste caso, a Corte IDH valorizou a iniciativa do Chile em realizar uma reforma legislativa alguns meses antes da sentença, pela qual se derrogou e modificou algumas normas que faziam referência ao crime de desacato, porém, também demonstrou profunda preocupação à manutenção do tipo penal no Código de Justiça Militar, bem, como com alterações, que, a exemplo do art. 264 do Código Penal, foi modificado para incluir um tipo criminal de "ameaça" às mesmas autoridades que constituíam, antes da reforma do referido Código, sujeitos passivos do crime de desacato.

Segundo a Corte Interamericana, o Código Penal chileno contempla uma descrição que é ambígua e não delineia claramente o alcance da conduta criminosa, o que poderia levar a interpretações amplas que permitiriam que a conduta anteriormente considerada como desacato sejam indevidamente penalizadas pelo tipo penal de ameaças, e alerta que, caso o Estado decidir preservar essa regra, deve especificar de que tipo de ameaças se trata, de tal modo que não se reprima a liberdade de pensamento e expressão. ${ }^{39}$

[...] o Estado deve adotar, em um prazo razoável, fossem as tomadas medidas necessárias para derrogar ou modificar qualquer normas internas que sejam incompatíveis com os padrões internacionais em matéria de liberdade de pensamento e expressão, de maneira tal que se permita que as pessoas possam exercer o controle democrático de todas as instituições estatais e de seus funcionários, por meio da liberdade de expressão de suas ideias e opiniões sobre as gestões que realizam, sem temer repressão posterior. ${ }^{40}$

\footnotetext{
${ }^{37}$ COSTA RICA, Corte Interamericana de Derechos Humanos. Caso Palamara Iribarne vs. Chile. Fondo, Reparaciones y Costas (Serie C No 135, 2005), 22 de novembro de 2005, p. 57, § 69. Jurisprudencia, San José, Costa Rica, 22 de novembro de 2005. Disponível em: www.corteidh.or.cr. Acesso em 18 jan. 2019.

${ }^{38}$ MAZZUOLI, Valerio de Oliveira. Direitos Humanos na Jurisprudência Internacional: sentenças, opiniões consultivas, decisões e relatórios internacionais. Colaboração de Monique Jeane Barbosa da Silva; Jennifer de Lara Gnoatto. Rio de Janeiro: Forense; São Paulo: Método, 2019, p. 628.

${ }^{39}$ COSTA RICA, Corte Interamericana de Derechos Humanos. Caso Palamara Iribarne vs. Chile. Fondo, Reparaciones y Costas (Serie C No 135, 2005), 22 de novembro de 2005, p. 62, § 92. Jurisprudencia, San José, Costa Rica, 22 de novembro de 2005. Disponível em: www.corteidh.or.cr. Acesso em 18 jan. 2019.

40 "[...] el Estado debe adoptar, en un plazo razonable, todas las medidas necesarias para derogar y modificar cualesquiera normas internas que sean incompatibles con los estándares internacionales en materia de libertad de pensamiento y de expresión, de manera tal que se permita que las personas puedan ejercer el control democrático de todas las instituciones estatales y de sus funcionarios, a través de la libre expresión de sus ideas y opiniones sobre las gestiones que ellas realicen, sin temor a su represión posterior." In: COSTA RICA, Corte Interamericana de Derechos

Revista de Direito Brasileira | Florianólopis, SC | v. 25 | n. 10 | p. 221-249 | Jan./Abr. 2020
} 
Conclui-se, assim, que os órgãos do Sistema Interamericano de Direitos Humanos guardam sérias restrições quanto à criminalização do desacato, ao reconhecerem amplamente o direito à liberdade de expressão como pilar da sociedade que almeja a efetiva democracia.

O cenário que se desenha no judiciário brasileiro e que se analisará adiante é, no entanto, o da manutenção da criminalização do desacato, desconsiderando-se, em certa medida, que a função da Comissão Interamericana, ao interpretar as normas do Sistema Interamericano, e da Corte em aplicá-las, corrobora para a correta interpretação da Convenção, e contribui decisivamente para a atividade jurisdicional dos Estados.

As manifestações dos órgãos que compõe o Sistema Americano, que em diversas oportunidades registraram que os delitos de desacato são incompatíveis com o direito à liberdade de expressão e pensamento, não são meras recomendações aos Estados-partes, mas parte de um processo de transfertilização e de reconhecimento expresso da complementariedade entre os diferentes sistemas de proteção dos direitos humanos. ${ }^{41}$

Vale dizer que todos os fundamentos à liberdade de expressão e argumentos aqui apresentados se aplicam tanto à Constituição Federal quanto à Convenção Americana de Direitos Humanos enquanto parâmetros para a verificação da compatibilidade vertical material das normas infraconstitucionais domésticas. A despeito das redações diversas e do disposto na Convenção ser mais extenso, as duas normativas abarcam o mesmo conteúdo deste direito fundamental e inalienável.

Assevera-se que, independentemente da adoção da posição até então prevalecente no STF (Convenção com hierarquia supralegal) ou da teoria de Valerio Mazzuoli ${ }^{42}$ (Convenção com hierarquia constitucional), a Convenção Americana de Direitos Humanos deve ser reconhecida como paradigma para o controle de convencionalidade, por se tratar de tratado internacional que trata diretamente dos direitos humanos. Contudo, ressalta-se, à luz da posição do STF, o único controle interno de convencionalidade cabível em face da Convenção Interamericana seria o controle em sua forma difusa, já que o tratado não possuiria hierarquia constitucional, o que não impede, como visto, sua realização pelo próprio Supremo Tribunal Federal.

Embora as manifestações da CIDH terem caráter recomendatório ${ }^{43}$ e as decisões da Corte IDH gerarem apenas efeitos inter partes $^{44}$, o intérprete que realiza o controle vertical de compatibilidade da norma nunca deve permitir que sua análise passe ao largo do princípio pro homine, do pacta sunt servanda e da efetivação máxima dos direitos humanos, levando sempre em conta as contribuições do Sistema Interamericano de Proteção aos Direitos Humanos, que sem

Humanos. Caso Palamara Iribarne vs. Chile. Fondo, Reparaciones y Costas (Serie C No 135, 2005), 22 de novembro de 2005, p. 102, § 254. Jurisprudencia, San José, Costa Rica, 22 de novembro de 2005. Disponível em: www.corteidh.or.cr. Acesso em 18 jan. 2019.

${ }^{41}$ Ver a respeito em: BASTOS JR., Luiz Magno P.; LOIS, Cecília Caballero. Comparativismo constitucional e tradução jurídica: aproximações iniciais ao problema da incorporação discursiva dos elementos não-nacionais. Revista de Direito Brasileira, São Paulo, SP, v. 20, n. 8, p. 62-80, mai./ago. 2018. Disponível em: https://indexlaw.org/index.php/rdb/article/view/3161/3989. Acesso em 18 mai. 2019.

${ }^{42}$ MAZZUOLI, Valerio de Oliveira. Teoria geral do controle de convencionalidade no direito brasileiro. Revista de Informação Legislativa, Brasília, a. 46, no 181, p. 113-139, jan./mar. 2009, p. 135.

43 “Art. 41.b - formular recomendações aos governos dos Estados membros, quando o considerar conveniente, no sentido de que adotem medidas progressivas em prol dos direitos humanos no âmbito de suas leis internas e seus preceitos constitucionais, bem como disposições apropriadas para promover o devido respeito a esses direitos" In: BRASIL. Decreto no 678, de 6 de novembro de 1992. Promulga a Convenção Americana sobre Direitos Humanos (Pacto de São José da Costa Rica), de 22 de novembro de 1969. Portal da Legislação, Brasília, DF, 21 out. 1969. Disponível em: www.planalto.gov.br. Acesso em: 15 mai. 2019.

44 “Art. 68.1 - Os Estados Partes na Convenção comprometem-se a cumprir a decisão da Corte em todo caso em que forem partes”. In: BRASIL. Decreto no 678, de 6 de novembro de 1992. Promulga a Convenção Americana sobre Direitos Humanos (Pacto de São José da Costa Rica), de 22 de novembro de 1969. Portal da Legislação, Brasília, DF, 21 out. 1969. Disponível em: www.planalto.gov.br. Acesso em: 15 mai. 2019.

Revista de Direito Brasileira | Florianólopis, SC | v. 25 | n. 10 | p. 221-249 | Jan./Abr. 2020 
dúvidas cumpre um papel de extrema relevância ao estender ou complementar direitos já assegurados constitucionalmente ${ }^{45}$.

Deve-se levar em conta o princípio da boa-fé, que obriga os Estados a realizarem seus melhores esforços para o efetivo cumprimento das manifestações da $\mathrm{CIDH}^{46}$, sendo este princípio consagrado também na Convenção de Viena Sobre Direito dos Tratados ${ }^{47}$. Ademais, atualmente defende-se a teoria do bloco de convencionalidade ${ }^{48}$, já reconhecida inclusive pela própria Corte IDH, devendo o controle de convencionalidade realizado internamente.

No julgado Cabrera García y Montiel Flores vs. México, de 26 de novembro de 2010, a Corte IDH assentou que, para exercer controle de convencionalidade, "os juízes e órgãos vinculados à administração da justiça devem ter em conta não somente o tratado, senão também a interpretação que lhe tenha dado a Corte Interamericana, intérprete última da Convenção Americana" 49.

Para tanto, tem-se como parâmetro não apenas a Convenção Americana de Direitos Humanos e demais instrumentos internacionais que versam sobre direitos humanos, mas também a jurisprudência da própria Corte acerca destes tratados ${ }^{50}$. Somente assim se assegura uma interação entre as jurisdições nacionais e interamericanas, com a finalidade de estabelecer padrões para a proteção efetiva dos direitos humanos ${ }^{51}$, conferindo-se também um caráter evolutivo às próprias disposições da Convenção a partir de sua constante interpretação vinculante por parte da Corte IDH.

\section{CONTROLE DE CONSTITUCIONALIDADE E CONVENCIONALIDADE: INSTRUMENTOS DE EFETIVAÇÃO DE DIREITOS}

No Brasil o controle da constitucionalidade dos atos normativos, pode ser realizado tanto de forma difusa ou concreta, quanto de forma concentrada ou abstrata, nesse último caso pelo Supremo Tribunal Federal (STF) a partir da atuação dos legitimados constantes no art. 103 da Constituição Federal ${ }^{52}$. Assim, tanto o juiz de primeiro grau quanto a cúpula do judiciário pátrio

\footnotetext{
${ }^{45}$ PIOVESAN, Flavia. Direitos Humanos e o Direito Constitucional Internacional. 14. ed. São Paulo: Saraiva, 2013, p. 170.

${ }^{46}$ RAMOS, André de Carvalho. Processo internacional de direitos humanos. 4ª ed. São Paulo: Saraiva, 2015 , p. 234.

${ }^{47}$ Cf., preâmbulo, arts. 26, 31.1, 46.2 e 69.2b. In: BRASIL. Decreto n ${ }^{\text {0 } 7.030, ~ d e ~} 14$ de dezembro de 2009. Promulga a Convenção de Viena sobre o Direito dos Tratados, concluída em 23 de maio de 1969, com reserva aos Artigos 25 e 66. Portal da Legislação, Brasília, DF, 15 dez. 2009. Disponível em: www.planalto.gov.br. Acesso em: 17 mai. 2019. 48 MAC-GREGOR, Eduardo Ferrer. Interpretación conforme y control difuso de convencionalidad: El nuevo paradigma para el juez mexicano. Estudios constitucionales, Santiago, v. 9, n. 2, p. 582-586, 2011. Disponível em: https://scielo.conicyt.cl/pdf/estconst/v9n2/art14.pdf. Acesso em: 19 jan. 2019.

49 “[...] los jueces y órganos vinculados a la administración de justicia deben tener en cuenta no solamente el tratado, sino también la interpretación que del mismo ha hecho la Corte Interamericana, intérprete última de la Convención Americana." In: COSTA RICA, Corte Interamericana de Derechos Humanos. Caso Cabrera García y Montiel Flores vs. México. Excepciones Preliminares, Fondo, Reparaciones y Costas (Serie C No 220, 2010), 26 de novembro de 2010, p. 86, § 225. Jurisprudencia, San José, Costa Rica, 26 de novembro de 2010. Disponível em: www.corteidh.or.cr. Acesso em 18 jan. 2019. A Corte IDH se manifestou no mesmo sentido nos seguintes casos: Liakat Ali Alibux vs. Surinam e Personas dominicanas y haitianas expulsadas vs. República Dominicana.

${ }^{50}$ HEEMANN, Thimotie Aragon; PAIVA, Caio. Jurisprudência Internacional de Direitos Humanos. 2. ed. Belo Horizonte: Cei, 2017, p. 49-50.

51 MAC-GREGOR, Eduardo Ferrer. Interpretación conforme y control difuso de convencionalidad: El nuevo paradigma para el juez mexicano. Estudios constitucionales, Santiago, v. 9, n. 2, p. 531-622, 2011. Disponível em: https://scielo.conicyt.cl/pdf/estconst/v9n2/art14.pdf. Acesso em: 19 jan. 2019, p. 585.

52 “Art. 103. Podem propor a ação direta de inconstitucionalidade e a ação declaratória de constitucionalidade: I - o Presidente da República; II - a Mesa do Senado Federal; III - a Mesa da Câmara dos Deputados; IV a Mesa de Assembleia Legislativa ou da Câmara Legislativa do Distrito Federal; V o Governador de Estado ou do Distrito Federal; VI - o Procurador-Geral da República; VII - o Conselho Federal da Ordem dos Advogados do Brasil; VIII -

Revista de Direito Brasileira | Florianólopis, SC | v. 25 | n. 10 | p. 221-249 | Jan./Abr. 2020
} 
realizam o controle da constitucionalidade, que pode ser definido como a análise da relação estabelecida entre a Constituição Federal e um comportamento ou ato que lhe é ou não conforme ou compatível, em uma relação de caráter normativo e valorativo ${ }^{53}$. A partir daí, chega-se à conclusão se tal comportamento ou ato é constitucional ou inconstitucional.

Este controle está ligado a própria natureza de obrigatoriedade de uma Constituição, conferindo-lhe, através da previsão de um mecanismo de anulação de atos inconstitucionais, a força normativa necessária para que efetivamente vincule as práticas perpetradas em determinado ordenamento. No entendimento de Kelsen, “[...] uma Constituição que, por não dispor de mecanismo de anulação, tolera a subsistência de atos e, sobretudo, de leis com ela incompatíveis, não passa de uma vontade despida de qualquer força vinculante" ${ }^{\text {. }}$.

Para Ronaldo Brêtas, a jurisdição constitucional, antes empregada para o exame de matéria jurídico constitucional afeta ao Estado, visando o controle de atos estatais e leis ordinárias que contrariassem os preceitos constitucionais, ampliou-se, passando a compreender a consagração de direitos fundamentais no texto constitucional, implantada por um sistema de garantias e mecanismos que assegure a efetividade dos direitos. ${ }^{55}$ A função jurisdicional ou jurisdição é, no entanto, atividade-dever do Estado, prestada pelos órgãos competentes. É realizada por meio do processo balizado nos princípios e regras constitucionais, objetivando a imperativa e imparcial realização do ordenamento jurídico. ${ }^{56}$

Neste sentido, ao lado do controle de constitucionalidade, tem se firmado também no Brasil a teoria do controle da convencionalidade dos atos normativos, que consiste na realização da compatibilização da produção normativa interna com os tratados de direitos humanos ratificados pelo governo e em vigor no país.

O instituto do controle de convencionalidade tem suas raízes na doutrina francesa, de análise da conformidade de uma lei em relação às convenções internacionais, pode ser exercido por um juiz sobre uma lei ou sobre todo ato administrativo, visando assegurar a superioridade dos compromissos internacionais e europeus que a França ratifica sobre as leis e os regulamentos internos. ${ }^{57}$

No Brasil, a temática teve como percursor e difusor Valerio de Oliveira Mazzuoli, que defende que o controle de convencionalidade se realiza em relação aos tratados de direitos humanos, que, segundo o autor terão status constitucional: formal e materialmente constitucionais

partido político com representação no Congresso Nacional; IX - confederação sindical ou entidade de classe de âmbito nacional.” In: BRASIL. Constituição da República Federativa do Brasil de 1988. Portal da Legislação, Brasília, DF, 5 de outubro de 1988. Disponível em: www.planalto.gov.br. Acesso em: 12 mai. 2019.

${ }^{53}$ MIRANDA, Jorge. Manual de Direito Constitucional. Coimbra: Coimbra Ed., 1983, p. 274.

${ }^{54}$ KELSEN, Hans. A garantia jurisdicional da Constituição. In: Jurisdição constitucional. Tradução do alemão por Alexandre Krug, do italiano por Eduardo Brandão e do francês por Maria Ermantina Galvão. São Paulo: Martins Fontes, 2003, p. 78.

${ }^{55}$ BRÊTAS, Ronaldo de Carvalho Dias. Processo Constitucional e Estado Democrático de Direito. $3^{\text {a }}$ ed., Belo Horizonte: Del Rey, 2015, p. 52-53.

${ }^{56}$ BRÊTAS, Ronaldo de Carvalho Dias. Fundamentos constitucionais da jurisdição no estado democrático de direito. In: GALUPPO, Marcelo Campos (Coord.). Constituição e democracia: fundamentos. Belo Horizonte: Fórum, 2009, p. 277-309.

57 SIQUEIRA, Bruno Luiz Weiler; RIBEIRO, Daniela Menengoti. Trabalho Escravo Contemporâneo: Sistema Global de Combate. Rio de Janeiro, 2018, p. 119.

Revista de Direito Brasileira | Florianólopis, SC | v. 25 | n. 10 | p. 221-249 | Jan./Abr. 2020 
se aprovados conforme art. $5^{\circ}, \S 3^{\circ 58}$ da $\mathrm{CF} / 88$ ou apenas materialmente constitucionais, caso não aprovados pelo quórum qualificado, devido ao disposto no art. $5^{\circ}, \S 2^{\text {o59 }}$ da Carta Maior. ${ }^{60}$

Oportuno destacar que a classificação da hierarquia dos tratados internacionais defendida por Valerio de Oliveira Mazzuoli se diferencia da adotada pela maioria (cinco votos contra quatro) do Supremo Tribunal Federal na ocasião do julgamento do Recurso Extraordinário 466.343/SP ${ }^{61}$ e do Habeas Corpus 87.585/TO ${ }^{62}$, em 03 de dezembro de 2008. Para a Corte brasileira, os tratados de direitos humanos não aprovados pela maioria qualificada do art. $5^{\circ}, \S 3^{\circ}$, da CF são classificados hierarquicamente como infraconstitucionais e supralegais, e os tratados não relacionados com os direitos humanos possuem valor legal ${ }^{63}$, enquanto que apenas os tratados aprovados conforme o disposição constitucional, teria valor Constitucional (de Emenda Constitucional). Esse entendimento foi acompanhado pela Corte Especial do Superior Tribunal de Justiça na ocasião do julgamento do Recurso Especial 914.253/SP ${ }^{64}$, em dezembro de 2009, sendo, portanto, posição solidificada nas duas cortes superiores.

O controle de convencionalidade, assim como o controle de constitucionalidade, pode se realizar tanto pela via difusa quanto concentrada. Nas palavras de Valerio de Oliveira Mazzuoli, tais vias de exercício do controle consolidam o entendimento Corte Interamericana de Direitos Humanos (Corte IDH) ${ }^{65}$ sobre a obrigação do Judiciário dos países membros do Sistema

58 “Art. $5^{\circ} . \S 3^{\circ}$ Os tratados e convenções internacionais sobre direitos humanos que forem aprovados, em cada Casa do Congresso Nacional, em dois turnos, por três quintos dos votos dos respectivos membros, serão equivalentes às emendas constitucionais." In: BRASIL. Constituição da República Federativa do Brasil de 1988. Portal da Legislação, Brasília, DF, 5 de outubro de 1988. Disponível em: http://www.planalto.gov.br/ccivil_03/constituicao/ConstituicaoCompilado.htm. Acesso em: 12 mai. 2019.

59 "Art. $5^{\circ}$. $§ 2^{\circ}$ Os direitos e garantias expressos nesta Constituição não excluem outros decorrentes do regime e dos princípios por ela adotados, ou dos tratados internacionais em que a República Federativa do Brasil seja parte”. In: BRASIL. Constituição da República Federativa do Brasil de 1988. Portal da Legislação, Brasília, DF, 5 de outubro de 1988. Disponível em: www.planalto.gov.br. Acesso em: 12 mai. 2019.

${ }^{60}$ MAZZUOLI, Valerio de Oliveira. Teoria geral do controle de convencionalidade no direito brasileiro. Revista de Informação Legislativa, Brasília, a. 46, nº 181, p. 113-139, jan./mar. 2009, p. 114.

${ }^{61}$ BRASIL, Supremo Tribunal Federal. Recurso Extraordinário no 466.343 - SP. Recorrente: Banco Bradesco SA; Recorrido: Luciano Cardoso Santos; Relator: Ministro Cezar Peluso. Brasília, DF, 03 de dezembro de 2009. Acompanhamento Processual, Brasília, DF, 11 de dezembro de 2008. Disponível em: http://portal.stf.jus.br. Acesso em: 15 jan. 2019.

${ }^{62}$ BRASIL, Supremo Tribunal Federal. Habeas Corpus 87.585 - TO (0006131-83.2005.0.01.0000). Paciente: Alberto de Ribamar Ramos Costa; Coatora: Superior Tribunal de Justiça; Relator: Ministro Marco Aurélio. Brasília, DF, 03 de dezembro de 2008. Acompanhamento Processual, Brasília, DF, 12 de dezembro de 2008. Disponível em: http://portal.stf.jus.br. Acesso em: 15 jan. 2019.

${ }^{63}$ Para Mazzuoli, os tratados comuns, que não versam sobre direitos humanos, é que são classificados como supralegais, encontram-se num nível hierárquico intermediário, estando abaixo da Constituição, mas acima da legislação infraconstitucional, não podendo ser revogados por lei posterior (posto não se encontrarem em situação de paridade normativa com as demais leis nacionais). Frente a estes tratados, o controle a ser realizado não seria o de convencionalidade, mas sim o controle de supralegalidade. In: MAZZUOLI, Valerio de Oliveira. Teoria geral do controle de convencionalidade no direito brasileiro. Revista de Informação Legislativa, Brasília. a. 46, n 181, p. 113-139, jan./mar. 2009, p. 121, 135-139.

${ }^{64}$ BRASIL, Superior Tribunal de Justiça. REsp 914253 - SP (2006/0283913-8). Recorrente: Fazenda do Estado de São Paulo; Recorrido: Marja Artefatos Técnicos de Borracha Ltda.; Relator: Ministro Luiz Fux. Brasília, DF, 18 de novembro de 2009. Revista Eletrônica da Jurisprudência, Brasília, DF, 02 de dezembro de 2009. Disponível em: www.stj.jus.br. Acesso em: 15 jan. 2019.

${ }^{65}$ O Brasil, ao ratificar a Convenção Interamericana sobre Direitos Humanos, "Pacto San Jose da Costa Rica", em 6 de novembro de 1992, se comprometeu a cumprir o que dispõe a referida Convenção. Porém, somente em 2002, através do Decreto $\mathrm{n}^{\mathrm{0}} 4.463 / 2002$, é que se promulgou a declaração de reconhecimento da competência obrigatória da Corte IDH, para fatos posteriores à 10 de dezembro de 1998. A retroatividade da competência da Corte para analisar os fatos ocorridos desde dezembro de 1998, Ainda que o decreto presidencial tenha sido promulgado em 2002, se dá em razão da aprovação do documento no Congresso Nacional brasileiro, através do Decreto Legislativo no 89 , em 3 dezembro de 1998, e da declaração de aceitação da competência obrigatória da Corte Interamericana ter sido depositada pelo Brasil, junto à Secretaria-Geral da Organização dos Estados Americanos, naquela data, qual seja, em 10 de dezembro de 1998.

Revista de Direito Brasileira | Florianólopis, SC | v. 25 | n. 10 | p. 221-249 | Jan./Abr. 2020 
Interamericano, em realizar a compatibilidade de suas leis com os tratados de direitos humanos ratificados e em vigor no país.

Os juízes e tribunais nacionais [estejam] obrigados a controlar ex officio a convencionalidade das leis, invalidando as normas domésticas incompatíveis com os tratados de direitos humanos em vigor no Estado. Trata-se de respeitar o que a Corte Interamericana de Direitos Humanos vem decidindo desde 2006, quando expôs a obrigação do Judiciário nacional em realizar o exercício de compatibilização das normas internas com os tratados de direitos humanos (em especial, a Convenção Americana sobre Direitos Humanos) ratificados e em vigor no país. ${ }^{66}$

O marco inicial de 2006, trazida na citação precedente, se refere a decisão da Corte Interamericana de Direitos Humanos (Corte IDH), tomada no Caso Almonacid Arellano e outros vs. Chile, que estabeleceu:

A Corte está ciente de que os juízes e os tribunais internos estão sujeitos ao império da lei, e, portanto, estão obrigados a aplicar as disposições vigentes no ordenamento jurídico. Mas quando um Estado ratifica um tratado internacional como a Convenção Americana, seus juízes, como parte do aparato de Estado, também estão submetidos a ela, o que os obriga a velar para que os efeitos das disposições da Convenção não sejam afetadas pela aplicação de leis contrárias ao seu objeto e propósito, e que não têm efeitos legais. Em outras palavras, o Poder Judiciário deve exercer uma espécie de "controle de convencionalidade" entre as normas legais internas aplicáveis aos casos específicos e a Convenção Americana sobre Direitos Humanos. (tradução livre) ${ }^{67}$

Na esteira de uma escala "vigência-validade-eficácia", tem-se que caso um ato normativo não guarde compatibilidade vertical material com a Constituição ou com os tratados internacionais que versem sobre direitos humanos em vigor no Brasil, este ato não terá validade no plano do direito doméstico, a despeito de poder estar vigente, devendo portando ser afastado pelo Poder Judiciário $^{68}$. Retomando, no primeiro caso (verificação da compatibilidade - juízo de parametricidade - vertical material com a CF) estar-se-á diante do controle de constitucionalidade e no segundo (verificação da compatibilidade - juízo de parametricidade - vertical material com tratados internacionais com temática de direitos humanos) do controle de convencionalidade do ato normativo.

A mesma lógica do controle de constitucionalidade enquanto mecanismo de anulação que confere força obrigatória à uma Constituição pode ser estendida ao controle de convencionalidade,

\footnotetext{
${ }^{66}$ MAZZUOLI, Valerio de Oliveira. O controle jurisdicional da convencionalidade das leis. 2. ed. rev. atual. e amp. São Paulo: Revista dos Tribunais, 2011, p. 151-152, p. 168.

67 "La Corte es consciente que los jueces y tribunales internos están sujetos al imperio de la ley y, por ello, están obligados a aplicar las disposiciones vigentes en el ordenamiento jurídico. Pero cuando un Estado ha ratificado un tratado internacional como la Convención Americana, sus jueces, como parte del aparato del Estado, también están sometidos a ella, lo que les obliga a velar porque los efectos de las disposiciones de la Convención no se vean mermadas por la aplicación de leyes contrarias a su objeto y fin, y que desde un inicio carecen de efectos jurídicos. En otras palabras, el Poder Judicial debe ejercer una especie de "control de convencionalidad" entre las normas jurídicas internas que aplican en los casos concretos y la Convención Americana sobre Derechos Humanos.” In: COSTA RICA, Corte Interamericana de Derechos Humanos. Caso Almonacid Arellano e outros vs. Chile. Excepciones Preliminares, Fondo, Reparaciones y Costas (Serie C No. 154, 2006), 26 de setembro de 2006 , p. 53. Jurisprudencia, San José, Costa Rica, de 26 de setembro de 2006. Disponível em: www.corteidh.or.cr. Acesso em 17 jan. 2019.

${ }^{68}$ MAZZUOLI, Valerio de Oliveira. Teoria geral do controle de convencionalidade no direito brasileiro. Revista de Informação Legislativa, Brasília, a. 46, no 181, p. 113-139, jan./mar. 2009, p. 119.
}

Revista de Direito Brasileira | Florianólopis, SC | v. 25 | n. 10 | p. 221-249 | Jan./Abr. 2020 
que permite o afastamento de atos inconvencionais. Assim, conforme bem colocado pelo Eminente Ministro Celso de Mello já na ocasião do julgamento do Habeas Corpus 87.585/TO, as normas que integram o ordenamento jurídico interno se submetem "a um duplo controle de ordem jurídica: o controle de constitucionalidade e, também, o controle de convencionalidade, ambos incidindo sobre as regras jurídicas de caráter doméstico" 69 .

Vale lembrar que as decisões proferidas pelos tribunais brasileiros em controle difuso de convencionalidade terão, em regra, apenas efeito inter partes, tendo em conta a alegação de inconvencionalidade ser incidental em relação à lide, enquanto no controle concentrado eventualmente exercido pelo Supremo Tribunal Federal o efeito será erga omnes e vinculante ${ }^{70}$. Por fim, ambos os controles verticais das normas produzidas internamente devem se dar independentemente da provocação pelas partes envolvidas na demanda, especialmente nos casos de controle difuso, por tratarem de matérias de ordem pública frente a qual os órgãos jurisdicionais estão autorizados a atuarem ex officio.

Neste sentido, tem-se que o controle de constitucionalidade e o controle de convencionalidade são legítimos instrumentos de efetivação de direitos, que se realiza pelo exercício da função jurisdicional do estado.

\subsection{O controle de convencionalidade do crime de desacato na jurisprudência brasileira}

A discussão quanto ao controle de convencionalidade é recente no Brasil. Uma das primeiras decisões judiciais pátrias a exercerem o controle difuso ou concreto de convencionalidade do crime de desacato que se tem conhecimento foi a proferida pelo Juiz Federal Edevaldo de Medeiros, da $5^{\text {a }}$ Subseção Judiciária de Mato Grosso do Sul, datada de 23 de junho de $2014^{71}$.

No caso, uma mulher havia sido denunciada pelo Ministério Público Federal por ter supostamente desacato uma magistrada eleitoral em 2012, no dia das eleições municipais, ocasião em que havia que "não estava nem aí pelo fato dela ser juíza" ao receber a ordem de deixar o interior da escola onde se realizavam as votações. A denunciada teria permanecido nas intermediações da escola, sendo presa em flagrante quando policiais federais encontraram material de campanha de seu marido no interior de seu veículo. Ao ser conduzida à delegacia, a mulher teria estendido a mão para a juíza e a cumprimentado, ironicamente: "parabéns, juíza. A senhora fez o seu trabalho".

O Juiz Federal entendeu, contudo, que a tipificação do crime contraria o art. 13 da Convenção, ressaltando que a CIDH possuía entendimento solidificado de que a figura do desacato se presta ao abuso como meio para silenciar opiniões impopulares, reprimindo o debate crítico essencial para o funcionamento das instituições democráticas. Dessa forma, rejeitou-se a denúncia proposta com base no art. 395, inc. II, do Código de Processo Penal ${ }^{72}$.

\footnotetext{
${ }^{69}$ BRASIL, Supremo Tribunal Federal. Habeas Corpus 87.585 - TO (0006131-83.2005.0.01.0000). Paciente: Alberto de Ribamar Ramos Costa; Coatora: Superior Tribunal de Justiça; Relator: Ministro Marco Aurélio. Brasília, DF, 03 de dezembro de 2008, p. 341. Acompanhamento Processual, Brasília, DF, 12 de dezembro de 2008. Disponível em: http://portal.stf.jus.br. Acesso em: 15 jan. 2019.

${ }^{70}$ MARTINS, Leonardo; MOREIRA, Thiago Oliveira. Constitucionalidade e Convencionalidade de Atos do Poder Público: concorrência ou hierarquia? Um contributo em face da situação jurídico constitucional brasileira. Anuario de Derecho Constitucional Latino Americano. Año XVII, Montevideo, p. 463-483, 2011, p. 476-478.

${ }^{71}$ MATO GROSSO DO SUL. Justiça Federal. Tribunal Regional Federal da $3^{\text {a }}$ Região. Seção Judiciária do Estado de Mato Grosso do Sul, Quinta Subseção, $1^{\mathrm{a}}$ Vara, Ponta Pora. Processo $n^{\mathbf{o}}$ 0000951-45.2013.403.6005. Consulta Processual - Varas. Ponta Porá - MS, 23 de junho de 2014. Disponível em: http://www.jfsp.jus.br/foruns-federais. Acesso em 20 jan. 2019.

72 “Art. 395. A denúncia ou queixa será rejeitada quando: [...] I - faltar pressuposto processual ou condição para o exercício da ação penal”. In: BRASIL. Decreto-lei no 3.689, de 3 de outubro de 1941. Código de Processo Penal. Portal da Legislação, Brasília, DF, 3 out. 1941. Disponível em: www.planalto.gov.br. Acesso em: 15 mai. 2019.

Revista de Direito Brasileira | Florianólopis, SC | v. 25 | n. 10 | p. 221-249 | Jan./Abr. 2020
} 
Outra decisão de primeira instância de especial importância, foi a proferida pelo Juiz Estadual de Santa Catarina Alexandre Morais da Rosa em 17 de março de $2015^{73}$, na qual absolveu um homem denunciado por desacato por ter afirmado que "não gostava de polícia e que eram todos lotes de bichos, arrogantes e que não serviam para nada" e que não devia esclarecimento algum sobre uma briga generalizada na qual estava envolvido, "muito menos para uma policial feminina, porque mulher era para estar em casa dormindo".

Realizando o controle difuso de convencionalidade e afirmando que "a manifestação pública de desapreço proferida por particular, perante agente no exercício da atividade Administrativa, por mais infundada ou indecorosa que seja, certamente não se consubstancia em ato cuja lesividade seja da alçada da tutela penal" 74 , o magistrado catarinense absolveu o acusado, declarando que a tipificação do desacato é nitidamente autoritária, e, portanto, reconhecendo que o fato não constituindo infração penal ${ }^{75}$.

A decisão, contudo, foi levada ao Tribunal de Justiça de Santa Catarina, que apesar de entender que o crime de desacato não fere o direito fundamental da liberdade de expressão por não se confundir com a afronta e falta de respeito direcionadas ao funcionário público no exercício da função ou em razão dela, reconheceu a extinção da punibilidade pela prescrição de pretensão punitiva estatal na modalidade retroativa, em razão do lapso de três anos ultrapassado entre o recebimento da denúncia e a data do julgamento naquele tribunal. ${ }^{76}$

No âmbito do Superior Tribunal de Justiça, a primeira decisão a reconhecer a incompatibilidade do art. 331 do Código Penal com Convenção Americana de Direitos Humanos, foi a proferida pela Quinta Turma, em 15 de dezembro de 2016, no Recurso Especial no 1.640 .084 - $\mathrm{SP}^{77}$, que reverteu a decisão da $3^{\mathrm{a}}$ Câmara de Direito Criminal do Tribunal de Justiça de São Paulo, na qual se consignou que a derrogação do crime de desacato só poderia se dar por meio de lei. O tribunal paulista registrou não haver uma incompatibilidade absoluta com o delito de desacato, uma vez que não se permite a ofensa e humilhação gratuita a funcionários públicos, o que ocorreu no caso dos autos, quando o apelante insultou os policiais militares ${ }^{78}$.

O acórdão da Quinta Turma do STJ, no entanto, afirmou que a Convenção Interamericana prevê a adoção de medidas legislativas ou de outra natureza para que os Estados Partes solucionem

${ }^{73}$ SANTA CATARINA. Justiça Estadual de Santa Catarina. 4ª Vara Criminal da Comarca da Capital. Ação Penal Procedimento Sumário, Autos n. 0067370-64.2012.8.24.0023. Autor: Ministério Público do Estado de Santa Catarina; Acusado: A. S. dos S. F.; Juiz Alexandre Morais da Rosa. Florianópolis, Santa Catarina, 17 de março de 2015. Consulta de Processos, Florianópolis, Santa Catarina, 18 de março de 2015. Disponível em: https://esaj.tjsc.jus.br Acesso em: 15 jan. 2019.

${ }^{74}$ SANTA CATARINA. Justiça Estadual de Santa Catarina. 4ª Vara Criminal da Comarca da Capital. Ação Penal Procedimento Sumário, Autos n. 0067370-64.2012.8.24.0023. Autor: Ministério Público do Estado de Santa Catarina; Acusado: A. S. dos S. F.; Juiz Alexandre Morais da Rosa. Florianópolis, Santa Catarina, 17 de março de 2015. Consulta de Processos, Florianópolis, Santa Catarina, 18 de março de 2015. Disponível em: https://esaj.tjsc.jus.br Acesso em: 15 jan. 2019.

75 “Art. 386. O juiz absolverá o réu, mencionando a causa na parte dispositiva, desde que reconheça: [...] III - não constituir o fato infração penal”. In: BRASIL. Decreto-lei no 3.689, de 3 de outubro de 1941. Código de Processo Penal. Portal da Legislação, Brasília, DF, 3 out. 1941. Disponível em: www.planalto.gov.br. Acesso em: 15 mai. 2019.

${ }^{76}$ SANTA CATARINA. Tribunal de Justiça do Estado de Santa Catarina. $3^{\text {a }}$ Câmara Criminal. Apelação $n^{\circ} 0067370$ 64.2012.8.24.0023. Apelante: Ministério Público do Estado de Santa Catarina; Apelado: Alex Sandro dos Santos Ferraz; Relator: Desembargador Moacyr de Moraes Lima Filho. Florianópolis, SC, 07 jun. 2016. Consulta de Processos - 2 ${ }^{\mathbf{0}}$ Grau, Florianópolis, 07 jun. 2016. Disponível em: https://esaj.tjsc.jus.br. Acesso em: 10 mai. 2019.

77 BRASIL, Superior Tribunal de Justiça. Quinta Turma. Recurso Especial no 1.640.084 - SP (2016/0032106-0). Recorrente: Alex Carlos Gomes; Recorrido: Ministério Público do Estado de São Paulo; Relator: Ministro Ribeiro Dantas. Brasília, DF, 15 dez. 2016. Consulta Processual, Brasília, DF, 01 fev. 2017. Disponível em: www.stj.jus.br. Acesso em: 10 mai. 2019.

${ }^{78}$ SÃO PAULO. Tribunal de Justiça do Estado de São Paulo. $3^{a}$ Câmara de Direito Criminal. Apelação $n^{\circ} 0000422$ 34.2012.8.26.0590. Apelante: Alex Carlos Gomes; Apelado: Ministério Público do Estado de São Paulo; Relator: Toloza Neto. São Paulo, SP, 12 ago. 2014. Consulta de Processos do $2^{\mathbf{0}}$ Grau, São Paulo, SP, 13 ago. 2014 , p. 11. Disponível em: https://esaj.tjsp.jus.br. Acesso em: 10 mai. 2019.

Revista de Direito Brasileira | Florianólopis, SC | v. 25 | n. 10 | p. 221-249 | Jan./Abr. 2020 
antinomias que possam limitar ou suprimir o efetivo exercício da liberdade de expressão, destacando a adoção do entendimento firmado pelo Supremo Tribunal Federal ${ }^{79}$, no sentido de que os tratados de direitos humanos, ratificados pelo país, têm força supralegal, e que toda lei antagônica às normas emanadas de tratados internacionais sobre direitos humanos é destituída de validade.

[...] no plano material, as regras provindas da Convenção Americana de Direitos Humanos, em relação às normas internas, são ampliativas do exercício do direito fundamental à liberdade, razão pela qual paralisam a eficácia normativa da regra interna em sentido contrário, haja vista que não se trata aqui de revogação, mas de invalidade. ${ }^{80}$

A Quinta Turma do STJ consignou que a punição de atos ofensivos contra agentes públicos é capaz de fazer com que o indivíduo se abstenha de usufruir do direito à liberdade de expressão, por medo de represálias institucionais. Concluiu, então, por unanimidade, que a criminalização do desacato não se coaduna com um Estado Democrático de Direito, que tem a liberdade de expressão como um de seus pilares, asseverando que a tipificação contraria o humanismo e o postulado pro homine, ao colocar o Estado - personificado em seus agentes - em posição de preponderância em relação ao indivíduo.

Passados pouco mais de cinco meses após a paradigmática decisão da Quinta Turma de dezembro de 2016 que se posicionou pela descriminalização da conduta, a Terceira Seção do STJ, proferiu entendimento diverso no julgamento do Habeas Corpus $\mathrm{n}^{\circ} 379.269-\mathrm{MS}^{81}$, de 24 de maio de 2017, no qual ficou definido que o tipo penal de desacato é compatível com a liberdade de expressão, que por sua vez, não se mostra um direito absoluto e está sujeita a limitações para a proteção moral e ordem públicas, como ocorre com a previsão do art. 331 do Código Penal.

No caso em análise, o paciente havia sido denunciado pelos delitos tipificados nos arts. 306 do Código de Trânsito Brasileiro (dirigir veículo automotor sob a influência de álcool), 330 e 331, ambos do Código Penal (desobediência e desacato).

Os Ministros da Terceira Seção do STJ acordaram, por maioria, não conhecer do habeas corpus, no entanto, quanto ao crime de desacato, o voto vencido do Ministro Relator Reynaldo Soares da Fonseca, que foi acompanhado pelo Ministro Ribeiro Dantas, reconhecia a inviabilizada a condenação por desacato com fundamento em norma interna incompatível com Tratado de Direitos Humanos (norma supralegal), do qual o Brasil é signatário, e concedia a ordem de ofício para excluir da ação penal o crime de desacato e determinando o prosseguimento da ação penal,

\footnotetext{
${ }^{79}$ BRASIL, Supremo Tribunal Federal. Recurso Extraordinário no 466.343 - SP. Recorrente: Banco Bradesco SA; Recorrido: Luciano Cardoso Santos; Relator: Ministro Cezar Peluso. Brasília, DF, 03 de dezembro de 2009. Acompanhamento Processual, Brasília, DF, 11 de dezembro de 2008. Disponível em: http://portal.stf.jus.br. Acesso em: 15 jan. 2019.

${ }^{80}$ BRASIL, Superior Tribunal de Justiça. Quinta Turma. Recurso Especial no 1.640 .084 - SP (2016/0032106-0). Recorrente: Alex Carlos Gomes; Recorrido: Ministério Público do Estado de São Paulo; Relator: Ministro Ribeiro Dantas. Brasília, DF, 15 dez. 2016. Consulta Processual, Brasília, DF, 01 fev. 2017. p. 1-2. Disponível em: www.stj.jus.br. Acesso em: 10 mai. 2019.

${ }^{81}$ BRASIL, Superior Tribunal de Justiça. Terceira Seção. Habeas Corpus $n^{0} 379.269$ - MS (2016/0303542-3). Impetrante: Defensoria Pública do Estado de Mato Grosso do Sul; Impetrado: Tribunal de Justiça do Estado de Mato Grosso do Sul; Paciente: Magno Leandro Santos Angelico; Relator: Ministro Reynaldo Soares da Fonseca; R.P/Acórdão: Ministro Antonio Saldanha Palheiro. Consulta Processual, Inteiro Teor do Acórdão, Documento: 1595452, Brasília, DF, 30 jun. 2017. Disponível em: www.stj.jus.br. Acesso em: 10 mai. 2019.
} 
quanto aos delitos previstos nos arts. $306^{82}$ do Código de Trânsito Brasileiro (CTB) e $330^{83}$ do $\mathrm{CP}^{84}$

O julgado teve, ainda, alteração de posicionamento de dois Ministros (Felix Fischer e Jorge Mussi), que no REsp. 1.640.084, haviam entendido pela incompatibilidade do desacato com a Convenção Americana de Direitos Humanos.

Ao considerarem que as deliberações da CIDH não se caracterizavam como vinculantes, mas tão e somente como possuidoras de "poder de embaraço" ou "mobilização da vergonha", a Terceira Seção afastou aprioristicamente, inclusive, a obrigação do cumprimento doméstico de eventual decisão da Corte IDH em processo que tenha como parte o Brasil, alegando a "soberania que é inerente ao Estado" a partir da aplicação da Teoria da Margem de Apreciação Nacional (margin of appreciation). ${ }^{85}$

Em 13 de março de 2018, a decisão da Segunda Turma do Supremo Tribunal Federal no Habeas Corpus 141.949 - $\mathrm{DF}^{86}$, negou o writ a um civil condenado pelo crime de desacato à militar que se encontrava no exercício de suas funções. Conforme a denúncia, paciente desacatou um $2^{\circ}$ sargento que se encontrava no exercício de sua função na $4^{\mathrm{a}}$ Seção do Batalhão da Guarda Presidencial, em Brasília, ao chamá-lo de "palhaço" na presença de outros militares. Condenado à pena de seis meses de detenção, em regime aberto, obteve o benefício do sursis (suspensão condicional da pena) pelo prazo de dois anos e o direito de apelar em liberdade. A condenação foi mantida pelo Superior Tribunal Militar (STM) ao julgar apelação, diante da qual se impetrou habeas corpus.

Segundo entendimento da maioria da Turma, nos termos do voto do Relator Ministro Gilmar Mendes, vencido o Ministro Edson Fachin, denegou-se a ordem, aplicando a tipificação do delito prevista no artigo $299^{87}$ do Código Penal Militar, reconhecendo sua compatibilidade com a Constituição Federal e com a Convenção Americana de Direitos Humanos (Pacto de São José da

\footnotetext{
82 “Art. 306. Conduzir veículo automotor com capacidade psicomotora alterada em razão da influência de álcool ou de outra substância psicoativa que determine dependência: Penas - detenção, de seis meses a três anos, multa e suspensão ou proibição de se obter a permissão ou a habilitação para dirigir veículo automotor." In: BRASIL. Lei ${ }^{\circ}$ 9.503, de 23 de setembro de 1997. Institui o Código de Trânsito Brasileiro. Portal da Legislação, Brasília, DF, 24 set. 1997. Disponível em: www.planalto.gov.br. Acesso em: 12 mai. 2019.

83 "Art. 330. Desobedecer a ordem legal de funcionário público: Pena - detenção, de quinze dias a seis meses, e multa." In: BRASIL. Decreto-lei no 2.848, de 7 de dezembro de 1940. Código Penal. Portal da Legislação, Brasília, DF, 31 dez. 1940. Disponível em: www.planalto.gov.br. Acesso em: 12 mai. 2019.

${ }^{84}$ BRASIL, Superior Tribunal de Justiça. Terceira Seção. Habeas Corpus no 379.269 - MS (2016/0303542-3). Impetrante: Defensoria Pública do Estado de Mato Grosso do Sul; Impetrado: Tribunal de Justiça do Estado de Mato Grosso do Sul; Paciente: Magno Leandro Santos Angelico; Relator: Ministro Reynaldo Soares da Fonseca; R.P/Acórdão: Ministro Antonio Saldanha Palheiro. Consulta Processual, Inteiro Teor do Acórdão, Documento: 1595452, Brasília, DF, 30 jun. 2017, p. 29. Disponível em: www.stj.jus.br. Acesso em: 10 mai. 2019.

${ }^{85}$ Frisa-se, no entanto, o equívoco da aplicação da teoria no julgado, que se consubstancia um "drible" ao Sistema Interamericano de Direitos Humanos. Isso porque a Teoria da Margem de Apreciação Nacional não poderia ser aplicada de forma ilimitada, sob pena de esvaziamento da própria proteção internacional aos direitos humanos, pois possibilitaria que Estado-juiz tomasse livremente qualquer decisão, desprezando-se, quando oportuno, as deliberações dos órgãos internacionais. In: GUERRA, Gustavo Rabay; MARCOS, Henrique Jerônimo Bezerra. O drible continental: a margem de apreciação nacional na decisão de convencionalidade do crime de desacato pelo Superior Tribunal de Justiça. Revista da Faculdade de Direito UFPR, Curitiba, PR, Brasil, v. 63, n. 2, p. 169-189, ago. 2018. Disponível em: https://revistas.ufpr.br/direito/article/view/59194. Acesso em 17 jan. 2019.

86 BRASIL, Supremo Tribunal Federal. Segunda Turma. Habeas Corpus n ${ }^{\circ} 141.949$ - DF (000287558.2017.1.00.0000). Impetrante: Rafael de Deus Garcia; Coator: Superior Tribunal Militar; Paciente: Admys Francisco de Sousa Gomes; Relator: Ministro Gilmar Mendes. Acompanhamento Processual, Inteiro Teor do Acórdão, Brasília, DF, 13 mar. 2018. Disponível em: http://portal.stf.jus.br. Acesso em: 10 mai. 2019.

87 “Art. 299. Desacatar militar no exercício de função de natureza militar ou em razão dela: Pena - detenção, de seis meses a dois anos, se o fato não constitui outro crime." In: BRASIL. Decreto-lei no 1.001, de 21 de outubro de 1969. Código Penal Militar. Portal da Legislação, Brasília, DF, 21 out. 1969. Disponível em: www.planalto.gov.br. Acesso em: 12 mai. 2019.
} 
Costa Rica. Asseverou-se que o "desacato constitui importante instrumento de preservação da lisura da função pública e, indiretamente, da própria dignidade de quem a exerce" 88 .

O Ministro Edson Fachin pediu vênias para divergir, e salientou que mais importante do que analisar a obrigatoriedade ou não dos precedentes do Sistema Interamericano, é investigar as razões pelas quais determinada conduta é ou não incompatível com a proteção dos direitos humanos. Recordou, porém, que a função da Comissão Interamericana, ao analisar as normas do Sistema Interamericano, é a de corroborar para a correta interpretação da Convenção, contribuindo decisivamente para a atividade jurisdicional dos Estados e da Corte, e que as manifestações dos órgãos que compõe o Sistema Americano, que em diversas oportunidades registraram que os delitos de desacato são incompatíveis com o direito à liberdade de expressão e pensamento, "não são meras recomendações aos Estados-partes, mas, verdadeira medida de interpretação evolutiva"89.

Em agosto de 2018, o ministro Celso de Mello, do Supremo Tribunal Federal (STF), indeferiu o pedido de Habeas Corpus $154143^{90}$, no qual a Defensoria Pública do Estado do Rio de Janeiro pedia o trancamento da ação penal de agosto de 2013, a que um colombiano responde, na Justiça fluminense, por ter desacatado guardas municipais que patrulhavam a orla de Copacabana e o abordaram com uma mercadoria exposta no calçadão, e por resistência à execução de ato legal da autoridade.

O juízo de primeira instância absolveu o colombiano quanto ao crime de desacato, entendendo que o artigo 331 não foi recepcionado pela ordem constitucional vigente. Porém, ao julgar recurso do Ministério Público estadual, o Tribunal de Justiça do Rio de Janeiro (TJ-RJ) reformou a decisão e determinou o prosseguimento da ação penal. No Superior Tribunal de Justiça (STJ), a Defensoria Pública tentou reverter a decisão, porém, sem sucesso. No STF, o decano Celso de Mello destacou que a conduta imputada ao denunciado, de desacatar funcionários públicos no exercício de suas funções, extrapola o direito à liberdade de expressão, que não pode amparar comportamentos delituosos, e acolhendo, ainda, o parecer da Procuradoria-Geral da República, indeferiu o pedido de habeas corpus.

A polêmica, contudo, ainda está distante de sua resolução. Isso porque o Conselho Federal da Ordem dos Advogados do Brasil questiona, atualmente, a criminalização do desacato através da Arguição de Descumprimento de Preceito Fundamental (ADPF) $496^{91}$ ajuizada no Supremo Tribunal Federal (STF) em outubro de 2017, tendo como relator o Ministro Roberto Barroso.

$\mathrm{Na}$ ADPF, a requerente alega que a norma viola os seguintes preceitos fundamentais: (i) a liberdade de expressão (art. $5^{\circ}$, IX, e art. 220, CF/88), porque as manifestações sobre agentes públicos são relevantes para o debate público, não devendo ser cerceadas; (ii) o princípio republicano, o Estado Democrático de Direito e o princípio da igualdade (art. $1^{\circ}$, caput e par. único, e art. $5^{\circ}, \mathrm{CF} / 88$ ), uma vez que a tipificação do crime de desacato subverte a titularidade do poder

88 BRASIL, Supremo Tribunal Federal. Segunda Turma. Habeas Corpus n ${ }^{\circ} 141.949$ - DF (000287558.2017.1.00.0000). Impetrante: Rafael de Deus Garcia; Coator: Superior Tribunal Militar; Paciente: Admys Francisco de Sousa Gomes; Relator: Ministro Gilmar Mendes. Acompanhamento Processual, Inteiro Teor do Acórdão, Brasília, DF, 13 mar. 2018, p. 11. Disponível em: http://portal.stf.jus.br. Acesso em: 10 mai. 2019.

89 BRASIL, Supremo Tribunal Federal. Segunda Turma. Habeas Corpus n ${ }^{\circ} 141.949$ - DF (000287558.2017.1.00.0000). Impetrante: Rafael de Deus Garcia; Coator: Superior Tribunal Militar; Paciente: Admys Francisco de Sousa Gomes; Relator: Ministro Gilmar Mendes. Acompanhamento Processual, Inteiro Teor do Acórdão, Brasília, DF, 13 mar. 2018, p. 17-20. Disponível em: http://portal.stf.jus.br. Acesso em: 10 mai. 2019.

${ }^{90}$ BRASIL, Supremo Tribunal Federal. Habeas Corpus no 154143 - RJ (0067240-87.2018.1.00.0000). Impetrante: Defensoria Pública Geral do Estado do Rio de Janeiro; Coator: Superior Tribunal de Justiça; Paciente: Trevian Ferney Aragon; Relator: Ministro Celso de Mello. Acompanhamento Processual, Decisão Monocrática, Brasília, DF, 20 mar. 2018. Disponível em: http://portal.stf.jus.br. Acesso em: 10 mai. 2019.

91 BRASIL, Supremo Tribunal Federal. Arguição de Descumprimento de Preceito Fundamental (ADPF) 496 (0012916-84.2017.1.00.0000). Requerente: Conselho Federal da Ordem dos Advogados do Brasil; Intimado: Presidência da República; Relator: Ministro Roberto Barroso. Acompanhamento Processual, Brasília, DF, 30 out. 2017. Disponível em: http://portal.stf.jus.br. Acesso em: 15 mai. 2019.

Revista de Direito Brasileira | Florianólopis, SC | v. 25 | n. 10 | p. 221-249 | Jan./Abr. 2020 
político, colocando o servidor público em condição de superioridade no que respeita ao cidadão comum, quando deveria lhe prestar contas; (iii) o princípio da legalidade (art. $5^{\circ}, \mathrm{XXXIX}, \mathrm{CF} / 88$ ), já que se trata de tipo penal excessivamente aberto, que dificulta a diferenciação entre a mera reclamação ou crítica e o insulto violador da dignidade da função pública.

De acordo com a entidade, a norma questionada não especifica a conduta de desatacar, trazendo uma normatização vaga, e que, em decorrência dessa imprecisão, o tipo penal do desacato tem reprimido a liberdade de expressão de cidadãos, que são intimidados a não se manifestarem diante de condutas praticadas por agentes públicos por receio de incorrer no tipo de desacato. ${ }^{92}$

Segundo a petição inicial do Conselho Federal OAB, o referido crime, além de flagelar a liberdade de expressão, também viola outros preceitos fundamentais, dentre os quais destaca-se o princípio republicano, que por sua vez pressupõe a igualdade formal entre as pessoas; a eleição dos detentores do poder político; a responsabilidade do chefe de governo e/ou do Estado, impondo-se a prestação de contas de suas condutas. ${ }^{93}$ No mérito, pede que se declare a não recepção do dispositivo pela ordem constitucional vigente.

Trata-se, nesse caso, de Arguição de Descumprimento de Preceito Fundamental, em que se defende a não recepção do art. 331 do Código Penal pela Constituição de 1988. Isso porque, conforme orientação adotada até então pelo Supremo Tribunal Federal, a Convenção não serviria como paradigma para o controle concentrado perante o STF por não ter sido aprovada internamente pelo quórum qualificado do art. $5^{\circ}, \S 3^{\circ}, \mathrm{CF}$, sendo, portanto, paradigma apenas do controle difuso de convencionalidade ${ }^{94}$.

Registra-se, ainda, que há petições da Defensoria Pública União e da Defensoria Pública do Estado de São Paulo ${ }^{95}$ perante a CIDH requerendo o reconhecimento da situação de infringência à liberdade de expressão no Brasil em razão da criminalização do desacato, com a possibilidade, inclusive, que os casos cheguem à Corte IDH.

Quanto às discussões no Congresso Nacional, há propostas legislativas em sentidos diametralmente opostos. Neste sentido, o anteprojeto do novo Código Penal, Projeto de Lei 236, de $2012^{96}$, em trâmite no Senado, no título dedicado aos crimes contra a Administração Pública, destaca-se a descriminalização do desacato, com a revogação desta tipificação do rol dos tipos penais, cabendo, para esses casos, a injúria qualificada. Por outro lado, os crimes contra a honra tiverem as suas penas majoradas no Projeto de Código, prevendo-se o aumento de pena para dois terços quando a vítima é funcionário público.

\section{CONSIDERAÇÕES FINAIS}

\footnotetext{
92 BRASIL, Supremo Tribunal Federal. Arguição de Descumprimento de Preceito Fundamental (ADPF) 496 (0012916-84.2017.1.00.0000). Requerente: Conselho Federal da Ordem dos Advogados do Brasil; Intimado: Presidência da República; Relator: Ministro Roberto Barroso. Acompanhamento Processual, Petição Inicial, Brasília, DF, 30 out. 2017, p. 2. Disponível em: http://portal.stf.jus.br. Acesso em: 15 mai. 2019.

93 BRASIL, Supremo Tribunal Federal. Arguição de Descumprimento de Preceito Fundamental (ADPF) 496 (0012916-84.2017.1.00.0000). Requerente: Conselho Federal da Ordem dos Advogados do Brasil; Intimado: Presidência da República; Relator: Ministro Roberto Barroso. Acompanhamento Processual, Petição Inicial, Brasília, DF, 30 out. 2017, p. 7. Disponível em: http://portal.stf.jus.br. Acesso em: 15 mai. 2019.

${ }^{94}$ MAZZUOLI, Valerio de Oliveira. O controle jurisdicional da convencionalidade das leis. $2^{\mathrm{a}}$ ed. rev. atual. e amp. São Paulo: Revista dos Tribunais, 2011, p. 151-152.

${ }^{9}$ SÃO PAULO, Tribunal de Justiça de São Paulo, 10ª Vara de Fazenda Pública. Ação Civil Pública n ${ }^{\circ} 2014 / 000759$ (1016019-17.2014.8.26.0053). Requerente: Defensoria Pública do Estado de São Paulo; Requerida: Fazenda Pública do Estado de São Paulo; Interessado: Pedro Leonel Pinto de Carvalho; Juiz: Otavio Tioiti Tokuda. Consulta de Processos do 1Grau, São Paulo, SP, 23 abr. 2014. Disponível em: http://esaj.tjsp.jus.br. Acesso em: 17 mai. 2019.

${ }^{96}$ BRASIL. Senado Federal. Projeto de Lei do Senado n ${ }^{\circ}$ 236, de 2012, Novo Código Penal. Autor: Senador José Sarney. Relator atual: Senador Rodrigo Pacheco. Senado Federal, Brasília, DF, 09 jul. 2012. Disponível em: www.senado.leg.br. Acesso em: 20 mai. 2019.
}

Revista de Direito Brasileira | Florianólopis, SC | v. 25 | n. 10 | p. 221-249 | Jan./Abr. 2020 
Há, no Brasil, recentes e profícuas discussões acerca descriminalização do desacato, tanto no âmbito legislativo brasileiro, como nas decisões proferidas pelo poder judiciário do Brasil e nos documentos emitidos pelos órgãos que compõe o Sistema Americano.

De acordo com o protegido pela Convenção e reconhecido pela Corte Interamericana, o direito à liberdade de pensamento e de expressão, para além de uma dimensão individual, é composta de uma dimensão social, que importa no reconhecimento de que todos têm direito de receber e difundir informações, e de defender os seus pontos de vista. Sendo, ainda, consequência lógica do direito à liberdade de pensamento e de expressão, a proibição da censura prévia.

Neste sentido, a Comissão Interamericana também tem contribuindo decisivamente para a atividade jurisdicional dos Estados, manifestando-se reiteradamente sobre a incompatibilidade dos delitos de desacato com o direito à liberdade de expressão e pensamento. Já nas Cortes superiores brasileiras (Superior Tribunal de Justiça e Supremo Tribunal Federal), as recentes decisões tomadas via alegação de inconvencionalidade pelo controle difuso, desenham o cenário de manutenção do tipo penal do desacato.

Os casos mencionados no decorrer deste trabalho, demonstram, de forma exemplificativa, as situações de tolhimento descabido e autoritário da liberdade de expressão, impedindo ou inibindo o cidadão de realizar, legitimamente, suas críticas e oposições ao Estado, ainda que, por vezes, tais atos possam soar espinhosos ou até ofensivos. A tênue linha entre a legítima crítica e a ofensa, quanto mais aos olhos do agente público, dificulta sobremaneira a manifestação de descontentamento com o serviço público prestado pela Administração Pública, pelo particular.

Realizando-se, então, a compatibilização vertical material do art. 331 do Código Penal com a Constituição Federal e a Convenção Americana de Direitos Humanos, conclui-se que os delitos de desacato são incompatíveis com o direito à liberdade de expressão e pensamento, devendo ser afastada sua aplicação em razão de sua inconstitucionalidade e inconvencionalidade.

No Brasil, assim como em outros países da América, o tipo penal do desacato contempla uma descrição que não delineia claramente o alcance da conduta criminosa, o que pode ensejar interpretações amplas e tendenciosas. Ad argumentandum tantum, se o tipo não infringe, por si só, a liberdade de expressão, permite que sejam praticados abusos que contrariam o direito fundamental, sendo possível aqui traçar um paralelo com a situação analisada pela Corte IDH no caso Palamara Iribarne vs. Chile.

É preciso se atentar para o fato de uma eventual revogação do art. 331 do Código Penal trazer, em substituição, tipos penais com outros nomen juris, como é o caso do anteprojeto do novo Código Penal em trâmite no Senado Federal, que adotou a 'injúria qualificada' em substituição ao tipo penal do desacato. Neste caso, não há de se falar em avanço rumo à efetivação de normas internas que sejam incompatíveis com os padrões internacionais em matéria de liberdade de pensamento e expressão, nem tão pouco de deferência ao Sistema Interamericano de Direitos Humanos, mas sim de uma evasão da garantia do direito dos cidadãos.

É necessário que haja a derrogar ou modificar, de maneira a permita que as pessoas possam exercer o controle democrático de todas as instituições estatais e de seus funcionários, por meio da liberdade de expressão de suas ideias e opiniões sobre as gestões que realizam, sem temer repressão posterior.

Considerando esses pontos é que as leis de desacato diversos países das Américas (Argentina, Paraguai, Costa Rica, Chile, Honduras, Panamá, Guatemala, Nicarágua e Bolívia) foram revogadas. Na Guatemala, a Corte Constitucional, declarou, em $1^{\circ}$ de fevereiro de 2006, a inconstitucionalidade dos delitos de desacato, e no mesmo sentido, o Tribunal Constitucional boliviano reconheceu, em 20 de setembro de 2012, a inconstitucionalidade da mesma conduta.

A jurisprudência pátria, contudo, ainda hesita em desclassificar o tipo penal, valendo-se de argumentos de toda ordem: desde o caráter não vinculante das deliberações da CIDH ou mesmo da Corte IDH, até a necessidade de manter a ordem pública e proteger o exercício digno e efetivo dos cargos públicos. 
Sobre tais argumentos, no entanto, pondera-se que tão importante quanto reconhecer a competência da Corte Interamericana, ao qual o Brasil manifestou expressa adesão, é fundamental investigar as razões pelas quais determinada conduta é ou não incompatível com a proteção dos direitos no âmbito do direito pátrio, sob pena de esvaziamento da própria proteção internacional aos direitos humanos, pois possibilita que os Estados tomam livremente qualquer decisão, desprezando-se, quando oportuno, as normas internacionais.

Ademais, a função da Comissão Interamericana, ao se manifestar sobre as normas do Sistema Interamericano, é a de corroborar para a correta interpretação, contribuindo decisivamente para a atividade jurisdicional tanto dos Estados e da própria Corte IDH. Nas palavras do Ministro Edson Fachin, tais documentos "não são meras recomendações aos Estados-partes, mas, verdadeira medida de interpretação evolutiva"97

Assim, em nome da própria segurança jurídica, há premente necessidade de posicionamento acerca do desacato, o que pode se dar com a manifestação do STF na Arguição de Descumprimento de Preceito Fundamental n 496/2017, ajuizada pelo Conselho Federal da Ordem dos Advogados do Brasil, em que se defende a não recepção do crime de desacato pela Constituição de 1988, havendo ainda a possibilidade de futura condenação do Brasil pela Corte IDH no caso de não provimento da ADPF.

\section{REFERÊNCIAS}

ALEXY, Robert. A Theory of Constitutional Rights. Trad. Julian Rivers. Oxford: Oxford University Press, 2002.

BARROSO, Luis Roberto. Colisão entre liberdade de expressão e direitos da personalidade. Critérios de ponderação. Interpretação constitucionalmente adequada do Código Civil e da Lei de Imprensa. Revista de direito administrativo, v. 235, p. 1-36, Rio de Janeiro, jan./mar. 2004.

BASTOS JR., Luiz Magno P.; LOIS, Cecília Caballero. Comparativismo constitucional e tradução jurídica: aproximações iniciais ao problema da incorporação discursiva dos elementos não-nacionais. Revista de Direito Brasileira, São Paulo, SP, v. 20, n. 8, p. 62-80, mai./ago. 2018. Disponível em: https://indexlaw.org/index.php/rdb/article/view/3161/3989. Acesso em 18 mai. 2019.

BOBBIO, Norberto. Igualdade e liberdade. 3. ed. Tradução de Nelson Coutinho. Rio de Janeiro: Ediouro, 1997.

BRASIL, Superior Tribunal de Justiça. Quinta Turma. Recurso Especial n ${ }^{\circ}$ 1.640.084 - SP (2016/0032106-0). Recorrente: Alex Carlos Gomes; Recorrido: Ministério Público do Estado de São Paulo; Relator: Ministro Ribeiro Dantas. Brasília, DF, 15 dez. 2016. Consulta Processual, Brasília, DF, 01 fev. 2017. Disponível em: www.stj.jus.br. Acesso em: 10 mai. 2019.

BRASIL, Superior Tribunal de Justiça. REsp 914253 - SP (2006/0283913-8). Recorrente: Fazenda do Estado de São Paulo; Recorrido: Marja Artefatos Técnicos de Borracha Ltda.; Relator: Ministro Luiz Fux. Brasília, DF, 18 de novembro de 2009. Revista Eletrônica da

97 BRASIL, Supremo Tribunal Federal. Segunda Turma. Habeas Corpus $\mathrm{n}^{\mathrm{o}} 141.949$ - DF (000287558.2017.1.00.0000). Impetrante: Rafael de Deus Garcia; Coator: Superior Tribunal Militar; Paciente: Admys Francisco de Sousa Gomes; Relator: Ministro Gilmar Mendes. Acompanhamento Processual, Inteiro Teor do Acórdão, Brasília, DF, 13 mar. 2018, p. 20. Disponível em: http://portal.stf.jus.br. Acesso em: 10 mai. 2019. 
Jurisprudência, Brasília, DF, 02 de dezembro de 2009. Disponível em: www.stj.jus.br. Acesso em: 15 jan. 2019.

BRASIL, Superior Tribunal de Justiça. Terceira Seção. Habeas Corpus no 379.269 - MS (2016/0303542-3). Impetrante: Defensoria Pública do Estado de Mato Grosso do Sul; Impetrado: Tribunal de Justiça do Estado de Mato Grosso do Sul; Paciente: Magno Leandro Santos Angelico; Relator: Ministro Reynaldo Soares da Fonseca; R.P/Acórdão: Ministro Antonio Saldanha Palheiro. Consulta Processual, Inteiro Teor do Acórdão, Documento: 1595452, Brasília, DF, 30 jun. 2017. Disponível em: www.stj.jus.br. Acesso em: 10 mai. 2019.

BRASIL, Supremo Tribunal Federal. Arguição de Descumprimento de Preceito Fundamental (ADPF) 496 (0012916-84.2017.1.00.0000). Requerente: Conselho Federal da Ordem dos Advogados do Brasil; Intimado: Presidência da República; Relator: Ministro Roberto Barroso. Acompanhamento Processual, Brasília, DF, 30 out. 2017. Disponível em: http://portal.stf.jus.br. Acesso em: 15 mai. 2019.

BRASIL, Supremo Tribunal Federal. Habeas Corpus 87.585 - TO (000613183.2005.0.01.0000). Paciente: Alberto de Ribamar Ramos Costa; Coatora: Superior Tribunal de Justiça; Relator: Ministro Marco Aurélio. Brasília, DF, 03 de dezembro de 2008. Acompanhamento Processual, Brasília, DF, 12 de dezembro de 2008. Disponível em: http://portal.stf.jus.br. Acesso em: 15 jan. 2019.

BRASIL, Supremo Tribunal Federal. Habeas Corpus nº 154143 - RJ (006724087.2018.1.00.0000). Impetrante: Defensoria Pública Geral do Estado do Rio de Janeiro; Coator: Superior Tribunal de Justiça; Paciente: Trevian Ferney Aragon; Relator: Ministro Celso de Mello. Acompanhamento Processual, Decisão Monocrática, Brasília, DF, 20 mar. 2018. Disponível em: http://portal.stf.jus.br. Acesso em: 10 mai. 2019.

BRASIL, Supremo Tribunal Federal. Recurso Extraordinário nº 466.343 - SP. Recorrente: Banco Bradesco SA; Recorrido: Luciano Cardoso Santos; Relator: Ministro Cezar Peluso. Brasília, DF, 03 de dezembro de 2009. Acompanhamento Processual, Brasília, DF, 11 de dezembro de 2008. Disponível em: http://portal.stf.jus.br. Acesso em: 15 jan. 2019.

BRASIL, Supremo Tribunal Federal. Recurso Extraordinário no 466.343 - SP. Recorrente: Banco Bradesco SA; Recorrido: Luciano Cardoso Santos; Relator: Ministro Cezar Peluso. Brasília, DF, 03 de dezembro de 2009. Acompanhamento Processual, Brasília, DF, 11 de dezembro de 2008. Disponível em: http://portal.stf.jus.br. Acesso em: 15 jan. 2019.

BRASIL, Supremo Tribunal Federal. Segunda Turma. Habeas Corpus n ${ }^{\circ} 141.949$ - DF (0002875-58.2017.1.00.0000). Impetrante: Rafael de Deus Garcia; Coator: Superior Tribunal Militar; Paciente: Admys Francisco de Sousa Gomes; Relator: Ministro Gilmar Mendes. Acompanhamento Processual, Inteiro Teor do Acórdão, Brasília, DF, 13 mar. 2018. Disponível em: http://portal.stf.jus.br. Acesso em: 10 mai. 2019.

BRASIL. Constituição da República Federativa do Brasil de 1988. Portal da Legislação, Brasília, DF, 5 de outubro de 1988. Disponível em: www.planalto.gov.br. Acesso em: 12 mai. 2019. 
BRASIL. Decreto no 678, de 6 de novembro de 1992. Promulga a Convenção Americana sobre Direitos Humanos (Pacto de São José da Costa Rica), de 22 de novembro de 1969. Portal da Legislação, Brasília, DF, 21 out. 1969. Disponível em: www.planalto.gov.br. Acesso em: 15 mai. 2019.

BRASIL. Decreto n ${ }^{\circ}$ 7.030, de 14 de dezembro de 2009. Promulga a Convenção de Viena sobre o Direito dos Tratados, concluída em 23 de maio de 1969, com reserva aos Artigos 25 e 66. Portal da Legislação, Brasília, DF, 15 dez. 2009. Disponível em: www.planalto.gov.br. Acesso em: 17 mai. 2019.

BRASIL. Decreto n ${ }^{\circ}$ 847, de 11 de outubro de 1890. Promulga o Codigo Penal. Portal da Legislação, Brasília, DF, 11 out. 1890. Disponível em: www.planalto.gov.br. Acesso em: 13 mai. 2019.

BRASIL. Decreto-lei no 1.001, de 21 de outubro de 1969. Código Penal Militar. Portal da Legislação, Brasília, DF, 21 out. 1969. Disponível em: www.planalto.gov.br. Acesso em: 12 mai. 2019.

BRASIL. Decreto-lei n ${ }^{\circ}$ 2.848, de 7 de dezembro de 1940. Código Penal. Portal da Legislação, Brasília, DF, 31 dez. 1940. Disponível em: www.planalto.gov.br. Acesso em: 12 mai. 2019.

BRASIL. Decreto-lei no 3.689, de 3 de outubro de 1941. Código de Processo Penal. Portal da Legislação, Brasília, DF, 3 out. 1941. Disponível em: www.planalto.gov.br. Acesso em: 15 mai. 2019.

BRASIL. Lei de 16 de dezembro de 1830. Manda executar o Codigo Criminal. Portal da Legislação, Brasília, DF, 16 dez. 1830. Disponível em: www.planalto.gov.br. Acesso em: 13 mai. 2019.

BRASIL. Lei no 9.099, de 26 de setembro de 1995. Dispõe sobre os Juizados Especiais Cíveis e Criminais e dá outras providências. Portal da Legislação, Brasília, DF, 26 de setembro de 1995. Disponível em: www.planalto.gov.br. Acesso em: 12 mai. 2019.

BRASIL. Lei n ${ }^{\circ}$ 9.503, de 23 de setembro de 1997. Institui o Código de Trânsito Brasileiro. Portal da Legislação, Brasília, DF, 24 set. 1997. Disponível em: www.planalto.gov.br. Acesso em: 12 mai. 2019.

BRASIL. Senado Federal. Projeto de Lei do Senado n 236, de 2012, Novo Código Penal. Autor: Senador José Sarney. Relator atual: Senador Rodrigo Pacheco. Senado Federal, Brasília, DF, 09 jul. 2012. Disponível em: www.senado.leg.br. Acesso em: 20 mai. 2019.

BRÊTAS, Ronaldo de Carvalho Dias. Fundamentos constitucionais da jurisdição no estado democrático de direito. In: GALUPPO, Marcelo Campos (Coord.). Constituição e democracia: fundamentos. Belo Horizonte: Fórum, 2009, p. 277-309.

BRÊTAS, Ronaldo de Carvalho Dias. Processo Constitucional e Estado Democrático de Direito. $3^{\mathrm{a}}$ ed., Belo Horizonte: Del Rey, 2015. 
CODERCH, Pablo Salvador. El derecho de la libertad. Colección: Estudios Constitucionales. Madri, Espanha: Centro de Estudios Políticos y Constitucionales, 1993.

COSTA RICA, Corte Interamericana de Derechos Humanos. Caso "La Última Tentación de Cristo" (Olmedo Bustos y otros) vs. Chile. Fondo, Reparaciones y Costas (Serie C No. 73, 2001), 05 de fevereiro de 2001. Jurisprudencia, San José, Costa Rica, 22 de novembro de 2005.

Disponível em: www.corteidh.or.cr. Acesso em 18 mai. 2019.

COSTA RICA, Corte Interamericana de Derechos Humanos. Caso Almonacid Arellano e outros vs. Chile. Excepciones Preliminares, Fondo, Reparaciones y Costas (Serie C No. 154, 2006), 26 de setembro de 2006. Jurisprudencia, San José, Costa Rica, de 26 de setembro de 2006. Disponível em: www.corteidh.or.cr. Acesso em 17 jan. 2019.

COSTA RICA, Corte Interamericana de Derechos Humanos. Caso Cabrera García y Montiel Flores vs. México. Excepciones Preliminares, Fondo, Reparaciones y Costas (Serie C No 220, 2010), 26 de novembro de 2010. Jurisprudencia, San José, Costa Rica, 26 de novembro de 2010. Disponível em: www.corteidh.or.cr. Acesso em 18 jan. 2019.

COSTA RICA, Corte Interamericana de Derechos Humanos. Caso Palamara Iribarne vs. Chile. Fondo, Reparaciones y Costas (Serie C No 135, 2005), 22 de novembro de 2005. Jurisprudencia, San José, Costa Rica, 22 de novembro de 2005. Disponível em: www.corteidh.or.cr. Acesso em 18 jan. 2019.

DELMAS-MARTY, Mireille. Résister, responsabiliser, anticiper. Seuil: Paris, France, 2013.

GUERRA, Gustavo Rabay; MARCOS, Henrique Jerônimo Bezerra. O drible continental: a margem de apreciação nacional na decisão de convencionalidade do crime de desacato pelo Superior Tribunal de Justiça. Revista da Faculdade de Direito UFPR, Curitiba, PR, Brasil, v. 63, n. 2, p. 173, ago. 2018. Disponível em: https://revistas.ufpr.br/direito/article/view/59194. Acesso em 17 jan. 2019.

GUERRA, Gustavo Rabay; MARCOS, Henrique Jerônimo Bezerra. O drible continental: a margem de apreciação nacional na decisão de convencionalidade do crime de desacato pelo Superior Tribunal de Justiça. Revista da Faculdade de Direito UFPR, Curitiba, PR, Brasil, v. 63, n. 2, p. 169-189, ago. 2018. Disponível em: https://revistas.ufpr.br/direito/article/view/59194. Acesso em 17 jan. 2019.

HEEMANN, Thimotie Aragon; PAIVA, Caio. Jurisprudência Internacional de Direitos Humanos. 2. ed. Belo Horizonte: Cei, 2017.

HOBBES, Thomas. Leviatã ou matéria, forma e poder de um Estado eclesiástico ou civil. Tradução: Alex Marins. São Paulo. Ed. Martin Claret, 2002.

KELSEN, Hans. A garantia jurisdicional da Constituição. In: Jurisdição constitucional. Tradução do alemão por Alexandre Krug, do italiano por Eduardo Brandão e do francês por Maria Ermantina Galvão. São Paulo: Martins Fontes, 2003. 
MAC-GREGOR, Eduardo Ferrer. Interpretación conforme y control difuso de convencionalidad: El nuevo paradigma para el juez mexicano. Estudios constitucionales, Santiago, v. 9, n. 2, p. 531-622, 2011. Disponível em: https://scielo.conicyt.cl/pdf/estconst/v9n2/art14.pdf. Acesso em: 19 jan. 2019.

MACHADO, Jónatas Eduardo Mendes. Liberdade de expressão: Dimensões Constitucionais da Esfera Pública no Sistema Social. Boletim da Faculdade de Direito da Universidade de Coimbra. Coimbra: Coimbra Editora, 2002.

MACLEOD, Christopher. John Stuart Mill. The Stanford Encyclopedia of Philosophy. Spring 2017 Edition. Disponível em: https://plato.stanford.edu/archives/spr2017/entries/mill/. Acesso em: 16 jan. 2018.

MARTINS, Leonardo; MOREIRA, Thiago Oliveira. Constitucionalidade e Convencionalidade de Atos do Poder Público: concorrência ou hierarquia? Um contributo em face da situação jurídico constitucional brasileira. Anuario de Derecho Constitucional Latino Americano. Año XVII, Montevideo, p. 463-483, 2011.

MATO GROSSO DO SUL. Justiça Federal. Tribunal Regional Federal da $3^{\text {a }}$ Região. Seção Judiciária do Estado de Mato Grosso do Sul, Quinta Subseção, $1^{\text {a }}$ Vara, Ponta Pora. Processo ${ }^{\circ}$ 0000951-45.2013.403.6005. Consulta Processual - Varas. Ponta Porá - MS, 23 de junho de 2014. Disponível em: http://www.jfsp.jus.br/foruns-federais. Acesso em 20 jan. 2019.

MAZZUOLI, Valerio de Oliveira. Direitos Humanos na Jurisprudência Internacional: sentenças, opiniões consultivas, decisões e relatórios internacionais. Colaboração de Monique Jeane Barbosa da Silva; Jennifer de Lara Gnoatto. Rio de Janeiro: Forense; São Paulo: Método, 2019.

MAZZUOLI, Valerio de Oliveira. O controle jurisdicional da convencionalidade das leis. $2^{\mathrm{a}}$ ed. rev. atual. e amp. São Paulo: Revista dos Tribunais, 2011.

MAZZUOLI, Valerio de Oliveira. Teoria geral do controle de convencionalidade no direito brasileiro. Revista de Informação Legislativa, Brasília, a. 46, n 181, p. 113-139, jan./mar. 2009.

MAZZUOLI, Valerio de Oliveira; GOMES, Luiz Flávio Gomes. Comentários à Convenção Americana sobre Direitos Humanos: Pacto de San José da Costa Rica. 4. ed. ver., atual. e ampl. São Paulo: Revista dos Tribunais, 2013.

MILL, John Stuart. On Liberty. Kitchener: Batoche Books, 2001.

MIRANDA, Jorge. Manual de Direito Constitucional. Coimbra: Coimbra Ed., 1983, p. 274.

MONTEIRO, Washington de Barros. O crime de desacato. Doutrinas Essenciais de Direito Penal, vol. 6, p. 443 - 450, DTR 2012\1581. São Paulo: Revista dos Tribunais, 2010. 
NUCCI, Guilherme de Souza. Código Penal Comentado. 15. ed. Rio de Janeiro: Forense, 2015.

ORGANIZACIÓN DE LOS ESTADOS AMERICANOS. Comisión Interamericana de Derechos Humanos (CIDH), Relatoría Especial para la Libertad de Expresión, Informes Anuales.

Washington DC: OEA. Disponível em: www.oas.org. Acesso em: 10 mai. 2019.

ORGANIZACIÓN DE LOS ESTADOS AMERICANOS. Comisión Interamericana de Derechos Humanos (CIDH), Decisiones, Solución Amistosa, Informe No 22/94, Caso 11012, Horacio Verbitsky, 20 de septiembre de 1994. Washington DC: OEA, 1994. Disponível em: www.cidh.oas.org. Acesso em: 10 mai. 2019.

ORGANIZACIÓN DE LOS ESTADOS AMERICANOS. Comisión Interamericana de Derechos Humanos (CIDH), Informe anual de la Comisión Interamericana de Derechos Humanos 1994, OEA/Ser.L/V/II.88, Doc. 9 rev., 17 febrero 1995. Washington DC: OEA, 1995. Disponível em: www.cidh.oas.org. Acesso em: 10 fev. 2019.

ORGANIZACIÓN DE LOS ESTADOS AMERICANOS. Comisión Interamericana de Derechos Humanos (CIDH), Declaración de Principios sobre Liberdad de Expresión 2000. Washington DC: OEA, 2000. Disponível em: https://www.cidh.oas.org/basicos/declaracion.htm. Acesso em: 16 fev. 2019.

PIOVESAN, Flavia. Direitos Humanos e o Direito Constitucional Internacional. 14. ed. São Paulo: Saraiva, 2013, p. 170.

PRADO, Luiz Régis. Curso de direito penal brasileiro. Vol. 4. São Paulo: Revista dos Tribunais, 2002, p. 506-507.

RAMOS, André de Carvalho. Processo internacional de direitos humanos. $4^{\mathrm{a}}$ ed. São Paulo: Saraiva, 2015, p. 234.

SALDANHA, Jania Maria Lopes. Cosmopolitismo jurídico: teorias e práticas de um direito emergente entre a globalização e a mundialização. Porto Alegre: Livraria do Advogado, 2018.

SANTA CATARINA. Justiça Estadual de Santa Catarina. $4^{\mathrm{a}}$ Vara Criminal da Comarca da Capital. Ação Penal - Procedimento Sumário, Autos n. 0067370-64.2012.8.24.0023. Autor: Ministério Público do Estado de Santa Catarina; Acusado: A. S. dos S. F.; Juiz Alexandre Morais da Rosa. Florianópolis, Santa Catarina, 17 de março de 2015. Consulta de Processos, Florianópolis, Santa Catarina, 18 de março de 2015. Disponível em: https://esaj.tjsc.jus.br Acesso em: 15 jan. 2019.

SANTA CATARINA. Tribunal de Justiça do Estado de Santa Catarina. $3^{\text {a }}$ Câmara Criminal. Apelação no 0067370-64.2012.8.24.0023. Apelante: Ministério Público do Estado de Santa Catarina; Apelado: Alex Sandro dos Santos Ferraz; Relator: Desembargador Moacyr de Moraes Lima Filho. Florianópolis, SC, 07 jun. 2016. Consulta de Processos - 2 Grau, Florianópolis, 07 jun. 2016. Disponível em: https://esaj.tjsc.jus.br. Acesso em: 10 mai. 2019. 
SÃO PAULO, Tribunal de Justiça de São Paulo, $10^{a}$ Vara de Fazenda Pública. Ação Civil Pública nº 2014/000759 (1016019-17.2014.8.26.0053). Requerente: Defensoria Pública do Estado de São Paulo; Requerida: Fazenda Pública do Estado de São Paulo; Interessado: Pedro Leonel Pinto de Carvalho; Juiz: Otavio Tioiti Tokuda. Consulta de Processos do $1^{\circ}$ Grau, São Paulo, SP, 23 abr. 2014. Disponível em: http://esaj.tjsp.jus.br. Acesso em: 17 mai. 2019.

SÃO PAULO. Tribunal de Justiça do Estado de São Paulo. $3^{\text {a }}$ Câmara de Direito Criminal. Apelação no 0000422-34.2012.8.26.0590. Apelante: Alex Carlos Gomes; Apelado: Ministério Público do Estado de São Paulo; Relator: Toloza Neto. São Paulo, SP, 12 ago. 2014. Consulta de Processos do $2^{\circ}$ Grau, São Paulo, SP, 13 ago. 2014, p. 11. Disponível em: https://esaj.tjsp.jus.br. Acesso em: 10 mai. 2019.

SARMENTO, Daniel. A liberdade de expressão e o problema do 'Hate-Speech'. In: Cristiano Chaves de Farias. (Org.). Leituras Complementares de Direito Civil: O direito civilconstitucional em concreto. Salvador: Jus Podium, 2007, p. 37-95.

SCANLON, Thomas. A theory of freedom of expression. Philosophy \& Public Affairs, p. 204226, vol. $1, \mathrm{n}^{\circ} 2,1972$.

SIQUEIRA, Bruno Luiz Weiler; RIBEIRO, Daniela Menengoti. Trabalho Escravo Contemporâneo: Sistema Global de Combate. Rio de Janeiro, 2018. 